\title{
ACS APPLIED ENERGY MATERIALS
}

\section{Article}

Subscriber access provided by LUNDS UNIV

\section{MnO2 and Reduced Graphene Oxide as Bifunctional Electro-catalysts for Li-O2 Batteries}

Lihua Zhu, Frieder Scheiba, Vanessa Trouillet, Melinte Georgian, Qiang

Fu, Angelina Sarapulpva, Florian Sigel, Weibo Hua, and Helmut Ehrenberg

ACS Appl. Energy Mater., Just Accepted Manuscript • DOI: 10.1021/acsaem.9b01047 • Publication Date (Web): 06 Sep 2019

Downloaded from pubs.acs.org on September 9, 2019

\section{Just Accepted}

"Just Accepted" manuscripts have been peer-reviewed and accepted for publication. They are posted online prior to technical editing, formatting for publication and author proofing. The American Chemical Society provides "Just Accepted" as a service to the research community to expedite the dissemination of scientific material as soon as possible after acceptance. "Just Accepted" manuscripts appear in full in PDF format accompanied by an HTML abstract. "Just Accepted" manuscripts have been fully peer reviewed, but should not be considered the official version of record. They are citable by the Digital Object Identifier (DOI@). "Just Accepted" is an optional service offered to authors. Therefore, the "Just Accepted" Web site may not include all articles that will be published in the journal. After a manuscript is technically edited and formatted, it will be removed from the "Just Accepted" Web site and published as an ASAP article. Note that technical editing may introduce minor changes to the manuscript text and/or graphics which could affect content, and all legal disclaimers and ethical guidelines that apply to the journal pertain. ACS cannot be held responsible for errors or consequences arising from the use of information contained in these "Just Accepted" manuscripts. 


\section{$\mathrm{MnO}_{2}$ and Reduced Graphene Oxide as Bifunctional Electro-catalysts for $\mathrm{Li}^{-} \mathrm{O}_{2}$ Batteries}

Lihua Zhu, ${ }^{\dagger}$ Frieder Scheiba, ${ }^{*},{ }^{\dagger}$ Vanessa Trouillet, ${ }^{\dagger}, \$$ Melinte Georgian,,${ }^{\star}$ Qiang Fu,${ }^{\dagger}$ Angelina Sarapulpva, ${ }^{\dagger}$ Florian Sigel ${ }^{\dagger}$ Weibo Hua ${ }^{\dagger}$ and Helmut Ehrenberg ${ }^{\dagger,+}$

Institute for Applied Materials -Energy Storage Systems (IAM-ESS), Karlsruhe Institute of Technology (KIT), Hermann-von-Helmholtz-Platz 1, 76344 Eggenstein-Leopoldshafen, Germany.

Helmholtz-Institute Ulm for Electrochemical Energy Storage (HIU), Helmholtzstrasse 11, 89081 Ulm, Germany.

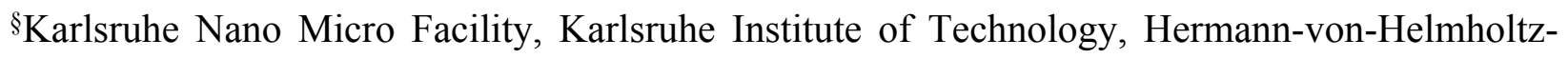
Platz 1, 76344, Eggenstein-Leopoldshafen, Germany.

KEYWORDS: $\mathrm{rGO}, \mathrm{MnO}_{2}$, interface, nano-sized, synergistic effect, mass transport, lithiated and non-lithiated, electron transfer. 


\begin{abstract}
An effective and cheap way to optimize the oxygen electro-catalyst of the cathode for $\mathrm{Li}-\mathrm{O}_{2}$ battery is to control the growth of a low amount of nano-sized transition metal oxides on the surface of the carbon electrode. This approach combines the advantages of surface, interface, and nano-size engineering. In this work, a $\mathrm{MnO}_{2}$ content of about $9 \mathrm{wt} \%$ is deposited on reduced graphene oxide $\left(\mathrm{MnO}_{2} @ \mathrm{rGO}\right)$. The $\mathrm{MnO}_{2}$ particles grow uniformly on the rGO surface with a particle size smaller than $20 \mathrm{~nm}$. The $\mathrm{MnO}_{2} @ \mathrm{rGO}$ composites were applied as cathode catalysts in $\mathrm{Li}-\mathrm{O}_{2}$ batteries, demonstrating an initial discharge capacity of $5139 \mathrm{mAh} \mathrm{g}^{-1}$ and a high capacity of $4262 \mathrm{mAh} \mathrm{g}^{-1}$ (80\% capacity retention) after 15 full discharge-charge cycles at a current density of $100 \mathrm{~mA} \mathrm{~g}^{-1}$. The outstanding performance can be attributed to the strong synergistic effect between the rGO framework and the nano-sized $\mathrm{MnO}_{2}$ particles on its surface. The rGO framework possesses a porous multilayer structure, which provides an excellent electrical conductivity, promotes oxygen and ion diffusion, and provides storage space for the discharge products. The nano-sized $\mathrm{MnO}_{2}$ possesses a high exposed surface, which enhances surface transport of $\mathrm{LiO}_{2}$ species and avoids the accumulation of discharge products on electrode surface. Furthermore, a transition between lithiated and non-lithiated manganese oxide during discharge and charge process was observed. This transition apparently helps to promote electron transfer between discharge products and the catalyst and thereby to reduce the overpotential of the oxygen evolution reaction.
\end{abstract}

\title{
1. INTRODUCTION
}

Porous air electrodes play different roles in the $\mathrm{Li}_{2} \mathrm{O}_{2}$ battery system: ( $\mathrm{i}$ ) it acts as an active catalyst material for the oxygen reduction/oxygen evolution reaction (ORR/OER). ${ }^{1}$ ( ii ) it serves as conductive framework for electron transfer. ${ }^{2}$ ( iii ) it provides as a matrix to deposit discharge 
products. $^{3,4}$ ( iv ) it forms a porous network that supports oxygen diffusion. ${ }^{5,6}$ Therefore, it is important to develop suitable oxygen electrode materials to improve the electrochemical performance of $\mathrm{Li}-\mathrm{O}_{2}$ batteries. Intensive research efforts have been devoted to the design and synthesis of appropriate oxygen electrode materials in recent years. Graphene stands out either as a metal-free catalyst or as support for metal or metal oxides catalysts, due to its good electronic conductivity, low cost, and large surface area. ${ }^{7,8}$ Due to the limited catalytic effect of pure graphene electrodes to the oxygen reduction reaction and oxygen evolution reaction ${ }^{9}$, heteroatom hybridization ( $\mathrm{N}^{10}, \mathrm{~S}^{11}$ and $\mathrm{B}$ doping), and combination with metals or metal oxides have been widely explored in recent years. ${ }^{12}$ Although noble metals $\left(\mathrm{Ru}^{13}, \mathrm{Au}^{12}, \mathrm{Sr}^{14}, \mathrm{Pd}^{15}\right.$ and etc.) exhibit decent electrochemical performance toward the ORR and OER, their scarcity and price have doomed them not to be widely used.

Manganese oxides are considered as promising catalysts due to their high abundance, low cost, environmental friendliness and excellent catalytic performance for both ORR and OER. ${ }^{16-17}$ Recently, different manganese compounds $\left(\alpha-\mathrm{MnO}_{2}, \mathrm{Mn}_{3} \mathrm{O}_{4}, \varepsilon-\mathrm{MnO}_{2}, \mathrm{MnO}_{\mathrm{x}}, \mathrm{MnCoO}_{4}\right.$ and etc $)$ with different morphologies and crystalline structures have been reported to have efficient catalytic activity for the OER/ORR of Li- $\mathrm{O}_{2}$ batteries. ${ }^{18-19}$ Metin's group in situ grew one-dimensional (1D) $\mathrm{MnO}_{2}$ nanowires on 2D mesoporous carbon nitride $\left(\mathrm{MnO}_{2} @ m p g-\mathrm{C}_{3} \mathrm{~N}_{4}\right)$. Benefiting from the effective stabilization of $\mathrm{Mn}^{3+}$ species in the electrocatalyst via the help of nitrogen functional groups, $\mathrm{MnO}_{2} @$ mpg- $\mathrm{C}_{3} \mathrm{~N}_{4}$ exhibited a high electrocatalytical efficiency for the OER. ${ }^{20}$ Cao's group synthesized $\alpha-\mathrm{MnO}_{2}$ nanorods on graphene nanosheets (GNs) and applied it as cathode for Li- $\mathrm{O}_{2}$ battery. ${ }^{16}$ The mass percent of $\alpha-\mathrm{MnO}_{2}$ in the composite is $80 \%$. The battery cycled 25 times with the cut-off capacity of $3000 \mathrm{mAh} \mathrm{g}^{-1}$ (based on the mass of GNs). Han et al. reported a $\mathrm{MnO}_{2}$ composite with hierarchically porous carbon (HPC) through the reaction of $\mathrm{KMnO}_{4}$ and carbon 
$\left(90 \mathrm{~min}\right.$ at $\left.50^{\circ} \mathrm{C}\right) .{ }^{21}$ The weight percentage of $\mathrm{MnO}_{2}$ was about $46 \%$. The composite was applied in a $\mathrm{Li}-\mathrm{O}_{2}$ battery, which exhibited low charge overpotential, good rate capacity and long cycle stability up to 300 cycles with a cut-off capacity of $1000 \mathrm{mAh} \mathrm{g}{ }^{-1} \cdot{ }^{21}$ However, the complex synthesis process of HPC makes it an expensive cathode material. Hwang's team developed an effective chemical way to optimize the electrocatalytical properties of $\alpha-\mathrm{MnO}_{2}$ nanowire by surface anchoring of highly oxidized selenate $\left(\mathrm{SeO}_{4}{ }^{2-}\right)$ clusters. ${ }^{22}$ The battery could be cycled 70 times with a cut-off capacity of $1000 \mathrm{mAh} \mathrm{g}{ }^{-1}$. Hwang's team also synthesized holey $2 \mathrm{D}_{\mathrm{Mn}_{2} \mathrm{O}_{3}}$ nanosheets by thermally induced phase transition of exfoliated layered $\mathrm{MnO}_{2}$ nanosheets. ${ }^{23}$ The Li- $\mathrm{O}_{2}$ battery with holey 2D nanosheets exhibited a cycleability of 33 cycles with a cut-off capacity of $1000 \mathrm{mAh} \mathrm{g}^{-1}$. Bi et al. obtained a 3D hollow $\alpha-\mathrm{MnO}_{2}$ framework (3D $\left.\alpha-\mathrm{MnO}_{2}\right)$ by a templateinduced hydrothermal reaction and subsequent annealing treatment. ${ }^{24}$ A very good cycling stability of 170 cycles with a cut-off capacity of $1000 \mathrm{~mA} \mathrm{hg}^{-1}\left(33 \% \alpha-\mathrm{MnO}_{2}\right.$ in catalyst material) was obtained with the $3 \mathrm{D}$ hollow $\alpha-\mathrm{MnO}_{2}$ framework catalyzed cathode. Surface morphologies and compositions of materials greatly influence their functional properties. In $\mathrm{Li}-\mathrm{O}_{2}$ batteries, the catalytically active part of the air electrode is its surface. ${ }^{25}$ Hence the modification of electrode material surface becomes an efficient and cheap way to enhance the catalytic activity. As we mentioned above, graphene has many advantages when applied as air electrode material for Li- $\mathrm{O}_{2}$ batteries. However, the low ORR/OER catalytic activity significantly limits its electrochemical performance as air electrode for $\mathrm{Li}^{-\mathrm{O}_{2}}$ batteries. Depositoin of catalysts on the graphene surface provides a way to improve the catalytic activity while preserving the advantages of graphene. Gao et al. reported a facile synchronous reduction strategy to fabricate a yolk-shell Ag-decorated $\mathrm{Co}_{3} \mathrm{O}_{4}$ $\left(\mathrm{Co}_{3} \mathrm{O}_{4} @ \mathrm{Co}_{3} \mathrm{O}_{4} / \mathrm{Ag}\right.$ hybrid $) .{ }^{26}$ It has been cycled stably for 80 times with the cut-off capacity of $1000 \mathrm{mAh} \mathrm{g}^{-1}$. It has also been reported that nano-sized catalysts can result in more exposed 
effective catalytic surface for ORR/OER. ${ }^{27}$ Hence loading of nano-sized catalysts on graphene surface can further optimize its catalytic activity. ${ }^{28}$

The combination of transition metal oxides and carbon have been widely explored as the cathode for Li- $\mathrm{O}_{2}$ battery. However, the detailed catalytic mechanism of the composite is unclear so far. Black's group explored the electrochemical performance of $\mathrm{Co}_{3} \mathrm{O}_{4}$ grown on reduced graphene oxide $\left(\mathrm{Co}_{3} \mathrm{O}_{4} @ \mathrm{RGO}\right)$ when applied in Li- $\mathrm{O}_{2}$ battery. ${ }^{29}$ They found an improvement of mass transport in both OER and ORR process by $\mathrm{Co}_{3} \mathrm{O}_{4} @ \mathrm{RGO}$.

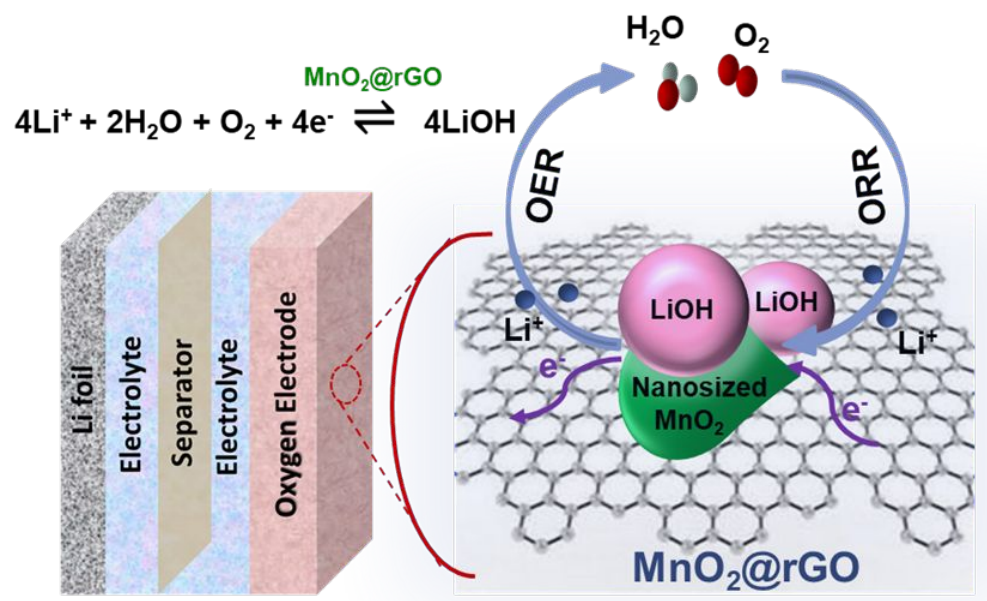

Scheme 1. Schematic structure of $\mathrm{Li}-\mathrm{O}_{2}$ battery catalyzed by $\mathrm{MnO}_{2} @ \mathrm{rGO}$. Nanosized $\mathrm{MnO}_{2}$ uniformly grows in situ on a rGO surface and the composite catalyzes the reversible formation and decomposition of $\mathrm{LiOH}$.

In this work, we assembled a novel kind of $\mathrm{MnO}_{2} @ \mathrm{rGO}$ nanocomposite material, consisting of a super low amount of nano-sized $\mathrm{MnO}_{2}$ grains on the surface of rGO (reduced graphene oxide, Dasheng Ltd.), which is highly efficient for the ORR/OER of $\mathrm{Li}^{-\mathrm{O}_{2}}$ batteries (Scheme 1). The $\mathrm{MnO}_{2} @ \mathrm{rGO}$ composite material is composed of $88 \mathrm{wt} \%$ of $\mathrm{rGO}$ and $9 \mathrm{wt} \% \mathrm{MnO}_{2}$. We also studied in details the catalytic mechanism of the $\mathrm{MnO}_{2} @ \mathrm{rGO}$ composite in a Li- $\mathrm{O}_{2}$ battery. The catalytic mechanism combines the promotion of mass transport of $\mathrm{Li}_{\mathrm{x}} \mathrm{O}_{2}$ species and electron transfer. 


\section{EXPERIMENTAL}

\section{1 $\mathrm{MnO}_{2} @$ rGO Material Preparation}

$\mathrm{MnO}_{2} @$ rGO was prepared by mixing $100 \mathrm{mg}$ rGO with $500 \mathrm{ml} 1 \mathrm{mM} \mathrm{KMnO} 4 / 5 \mathrm{mM} \mathrm{Na}_{2} \mathrm{SO}_{4}$. The mixture was stirred for $1 \mathrm{~h}$. This procedure relies on the chemical reaction between $\mathrm{KMnO}_{4}$ and graphitic carbon to generate $\mathrm{MnO}_{2}\left(\mathrm{C}+2 \mathrm{KMnO}_{4} \rightarrow \mathrm{K}_{2} \mathrm{MnO}_{4}+\mathrm{MnO}_{2}+\mathrm{CO}_{2} \uparrow\right)$. The multilayer rGO served as reactive template to grow the $\mathrm{MnO}_{2}$. This constrains the $\mathrm{MnO}_{2}$ growth rate and thereby the aggregation of $\mathrm{MnO}_{2}$ nanoparticles is avoided. $\mathrm{Na}_{2} \mathrm{SO}_{4}$ can increase the solubility of $\mathrm{CO}_{2}$ in solution and thereby slows down the chemical reaction, which is beneficial to obtain small particles. The obtained suspension was collected by suction filtration and washed with distilled water several times. The resulting product was dried at $80^{\circ} \mathrm{C}$ for $12 \mathrm{~h}$ in the oven.

\subsection{Cell Preparation and Eelectrochemical Measurement}

The catalyst material was first mixed with PVDF (PVDF6020, Solvay) in N-methyl pyrrolidone (NMP, Merck KGaA) solvent with a mass ratio of 7:3 ( $\left.\mathrm{MnO}_{2} @ \mathrm{rGO}: \mathrm{PVDF}\right)$. Then the slurry was coated on carbon paper (H23 I2, QUINTECH). $\mathrm{Li}_{2} \mathrm{O}_{2}$ cells were assembled using a Swagelok® cell construction. $\mathrm{Li}_{2} \mathrm{O}_{2}$ batteries consisting of a metallic $\mathrm{Li}$ foil, a glass fiber separator (Whatmann ${ }^{\circledR} \mathrm{GF} / \mathrm{B}$ ), $\mathrm{MnO}_{2} @ \mathrm{rGO}$ and the electrolyte were assembled inside an Ar-filled glove box $\left(<0.1 \mathrm{ppm}\right.$ of both oxygen and $\left.\mathrm{H}_{2} \mathrm{O}\right)$. As electrolyte $0.25 \mathrm{M}$ lithium bis(trifluoromethane)sulfonamide (LiTFSI) in tetra(ethylene) glycol dimethyl ether (TEGDME) was used. According to the Stokes-Einstein equation, lower Li salt concentration of $0.25 \mathrm{M}$ decreases the electrolyte viscosity and thereby increases the oxygen diffusion coefficient. This leads to high oxygen concentration and thereby contributes to a higher discharge capacity and rate capability (the ratedetermining step of the oxygen reduction reaction depends first order on the concentration of 
oxygen). The gas environment used for the electrochemical test was oxygen with trace water. The determination of the exact amount of water in the gas stream or taken up by the cell during operation was not possible. However, it has been demonstrated by many other research groups that traces of water improve the electrochemical performance of $\mathrm{Li}^{-} \mathrm{O}_{2}$ batteries. ${ }^{30,31}$ Electrochemical measurements were carried out on a VSP (Bio-Logic, France) multichannel potentiostat test system at room temperature. Galvanostatic discharge/charge tests were operated at room temperature in the range of 2.3-4.5 V. The cyclic voltammograms $(\mathrm{CV})$ were tested at $0.1 \mathrm{mV} \mathrm{s}^{-1}$. Current densities and specific capacities specified in this paper were calculated based on the total catalyst weight $\left(\mathrm{MnO}_{2}+\mathrm{rGO}\right)$.

\subsection{Characterization of the Raw Materials and the Discharged/Charged Electrodes}

SEM (scanning electron microscope, Zeiss Supra 55) was applied to characterize the morphology of the raw catalyst materials and the pristine/discharged/charged electrodes. $\mathrm{N}_{2}$ adsorption and desorption isotherms were measured with a Micromeritics instrument at $77 \mathrm{~K}$. X-ray diffraction (XRD) patterns of the raw catalyst materials and the pristine/discharged/charged electrodes were examined on STOE STADI P with Ag $\mathrm{K}_{\alpha}$ radiation $(\lambda=0.559407 \AA)$ or $\mathrm{Co} \mathrm{K}_{\alpha}$ radiation $(\lambda=1.78896$ $\AA$ ) at room temperature in Debye-Scherrer geometry (the capillary diameter: $0.5 \mathrm{~mm}$ ). XRD with $\mathrm{Ag} \mathrm{K}_{\alpha}$ radiation has higher energy and stronger penetration than $\mathrm{Co} \mathrm{K}_{\alpha}$ radiation, which makes it superior to analyze structures of metallic compounds. Hence we applied XRD with $\mathrm{Ag} \mathrm{K}_{\alpha}$ radiation to analyze the structure of raw catalyst materials. Due to its lower energy Co $\mathrm{K}_{\alpha}$ radiation is more strongly scattered by compounds with low electron density, which makes it superior to analyze the structure of discharge products. Rietveld refinement was employed to analyze the diffraction data of the discharge products using the FullProf software package. ${ }^{32}$ The discharged and charged electrodes was disassembled and washed in a glovebox. Then the discharge products were 
removed from the electrode surface and filled in a glass capillary $(\mathrm{D}=0.5 \mathrm{~mm})$ and sealed to avoid air contact during measurement. For Raman measurements, a Labram Evolution HR from Horiba was used, which was equipped with HeNe-Laser (633 nm, $17 \mathrm{~mW})$ and a CCD detector (Horiba). Besides, a 600 grating was used to split the measurement signal. For the raw material, a $\times 100$ objective lens was used for the measurements and the data was collected for 30 seconds with the laser power set to $4.25 \mathrm{~mW}$. For better signal-to-noise ratio, five measurements were added. $\mathrm{A} \times 50$ objective lens was used for the measurements of the pristine/discharged/charged electrodes. The data was collected for 60 seconds with the laser power set to $4.25 \mathrm{~mW}$. Again five measurements were added. The discharged and charged electrodes were mounted in a sealed cell with a quartz window inside a glovebox to protect them against air contact. Thermal analysis (TG) of $\mathrm{MnO}_{2} @ \mathrm{rGO}$ was carried out in air atmosphere with a heating rate of $5{ }^{\circ} \mathrm{C} \mathrm{min}-1$ to $1000{ }^{\circ} \mathrm{C}$ using a Netzsch STA 449 C Jupiter. The surface elemental compositions and oxidation state of elements in the $\mathrm{MnO}_{2} @ \mathrm{rGO}$ were determined by X-ray photoelectron spectroscopy (XPS). XPS was performed using a K-Alpha spectrometer (ThermoFisher Scientific, East Grinstead, UK) equipped with a microfocused, monochromated Al Ka X-ray source ( $400 \mu \mathrm{m}$ spot size). A glovebox with argon atmosphere directly attached to the spectrometer enabled an air free insertion of the samples into the load lock. The kinetic energy of the electrons was measured by a $180^{\circ}$ hemispherical energy analyzer operated in constant analyzer energy mode (CAE) at $50 \mathrm{eV}$ pass energy for elemental spectra. The K-Alpha charge compensation system was employed during analysis, using electrons of $8 \mathrm{eV}$ energy, and low-energy argon ions to prevent any localized charge build-up. Data acquisition and processing using the Thermo Avantage software is described elsewhere. ${ }^{33}$ The spectra were fitted with one or more Voigt profiles (BE uncertainty: $\pm 0.2 \mathrm{eV}$ ) and Scofield sensitivity factors were applied for quantification. ${ }^{34}$ All spectra were referenced to the C $1 \mathrm{~s}$ 
graphitic peak at $284.4 \mathrm{eV}$ binding energy controlled by means of the well-known photoelectron peaks of $\mathrm{Cu}, \mathrm{Ag}$ and $\mathrm{Au}$ respectively. X-ray absorption near edge structure (XANES) measurements were carried out at PETRA-III beamline P65 at DESY in Hamburg and recorded in quick-XAS (7 min/spectrum) mode in fluorescence geometry using a PIPS diode. The Mn K-edge of $\mathrm{MnO}_{2} @ \mathrm{rGO}$ was measured at room temperature with a Si (111) crystal monochromator. The energy was calibrated by the absorption edge of a Mn foil, which was measured in parallel with other samples. Standard materials were $\mathrm{MnO}, \mathrm{Mn}_{2} \mathrm{O}_{3}$, and $\mathrm{MnO}_{2}$. The XAS spectra were processed with the DEMETER software package. ${ }^{35}$ To further characterize further the morphology and structure of the samples, transmission electron microscopy was employed. Sample preparation for TEM consisted in the dispersion of the sample in high purity ethanol and depositing a droplet on a carbon-coated gold grid. The TEM analysis was performed on a Titan 80-300 electron microscope (FEI), equipped with a CEOS image aberration corrector, high angle annular dark field (HAADF) and a scanning transmission electron microscopy (STEM) detector as well as a Tridiem 863 Gatan image filter (GIF). The microscope was operated at an accelerating voltage of $300 \mathrm{kV}$. Elemental analysis measurements were carried out to determine the $\mathrm{MnO}_{2}$ loading by inductively coupled plasma mass spectrometry (ICP-MS, 7500ce, Agilent) after $\mathrm{MnO}_{2}$ was completely dissolved in acid.

\section{RESULTS AND DISCUSSION}

The obtained $\mathrm{MnO}_{2} @$ arGO sample was analyzed by SEM to investigate the morphology. SEM of the templated rGO sample (Figure 1a) clearly shows 3D multilayer structure. After $\mathrm{MnO}_{2}$ deposition, this 3D multilayer structure is preserved (Figure 1b), assuring a high surface area to hold the discharge products. To determine the morphology, distribution and crystal structure of 
the $\mathrm{MnO}_{2}$ particles, STEM and high resolution TEM analyses were carried out. STEM image of the sample show that the $\mathrm{MnO}_{2}$ nanoparticles have diameters smaller than $20 \mathrm{~nm}$ and are uniformly dispersed on the rGO surface (Figure 1c and d). For a more detailed investigation of the $\mathrm{MnO}_{2} @$ rGO composite, STEM-EDX elemental mappings (Manganese, Oxygen and Carbon) were recorded (Figure. S1a-d). The mappings confirm the uniform distribution of $\mathrm{MnO}_{2}$ particles on the rGO surface. The HRTEM imaging presented in Figure 1e further confirms that nano-sized crystalline $\mathrm{MnO}_{2}$ particles are grown on rGO. The uniform distribution can be attributed to the presence of reactive sites on the $\mathrm{rGO}$ surface, which aid the $\mathrm{MnO}_{2}$ formation and it will be partially consumed by the chemical reaction with $\mathrm{KMnO}_{4}$. Since the rGO template constrains the $\mathrm{MnO}_{2}$ growth rate, the aggregation of $\mathrm{MnO}_{2}$ nanoparticles is avoided. Further the low $\mathrm{KMnO}_{4}$ concentration of the solution leads to a low amount of $\mathrm{MnO}_{2}$ deposited on the rGO surface. All these factors promote the formation of the unique structure of the $\mathrm{MnO}_{2} @ \mathrm{rGO}$ composite.

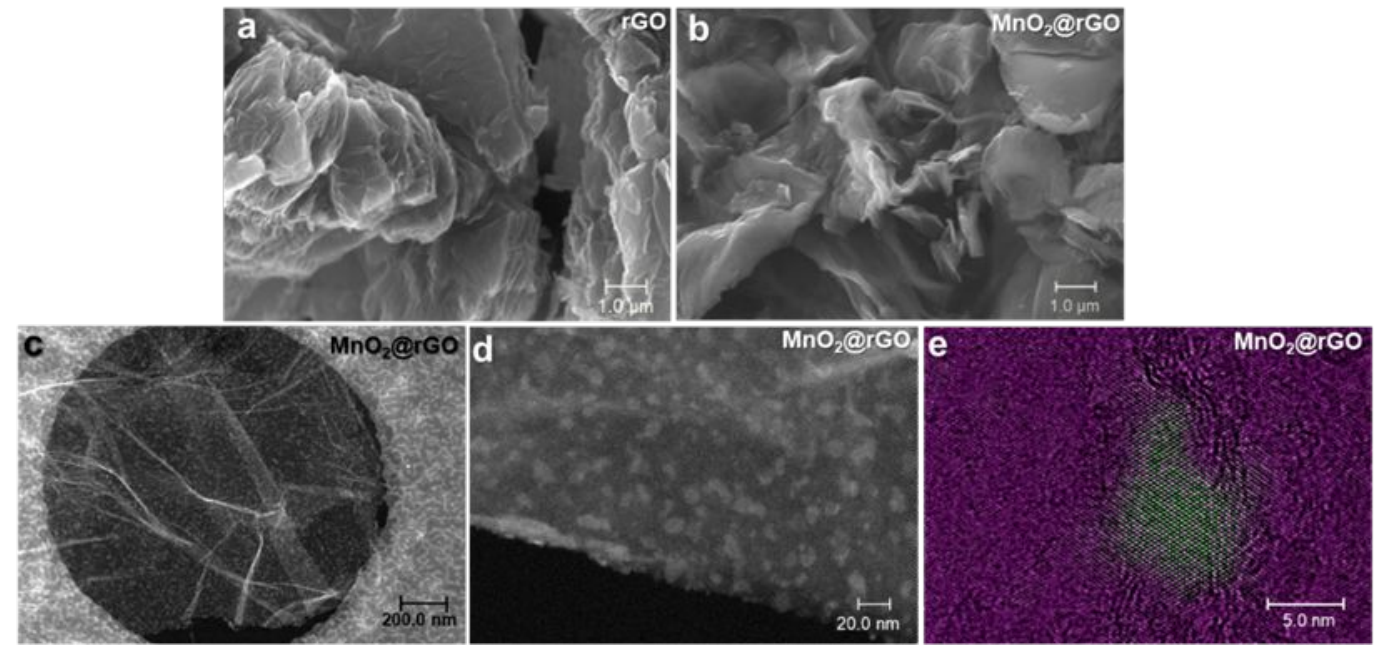

Figure 1. SEM images of raw rGO (a) and $\mathrm{MnO}_{2} @$ rGO composite (b); (c) and (d) STEM images of $\mathrm{MnO}_{2} @ \mathrm{rGO}$; (e) Composed HRTEM image from the inverse FFT of $\mathrm{MnO}_{2} @ \mathrm{rGO}$ catalyst. The purple part is rGO substrate and the green part is $\mathrm{MnO}_{2}$ particle. 


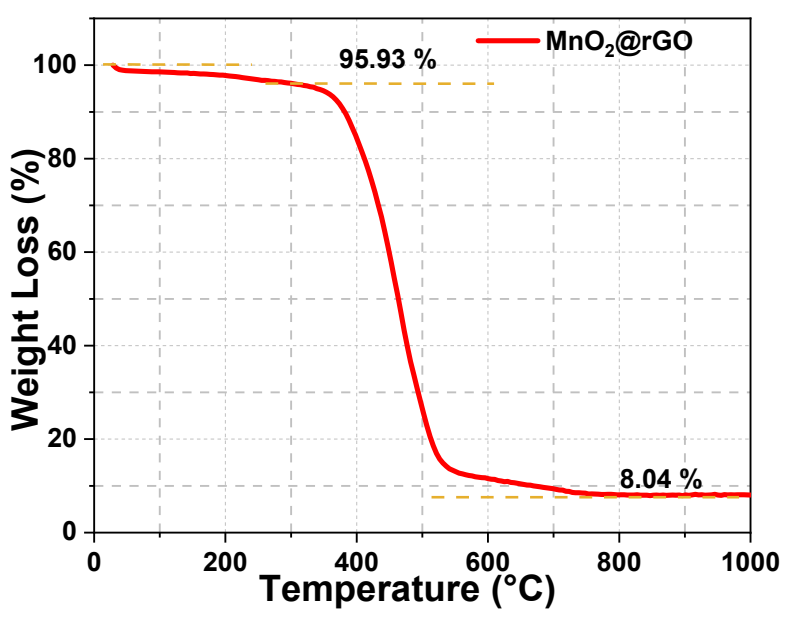

Figure 2. TG curve of $\mathrm{MnO}_{2} @ \mathrm{rGO}$ composite.

TG was used to examine the $\mathrm{MnO}_{2}$ content of the $\mathrm{MnO}_{2} @ \mathrm{rGO}$ composite (Figure 2). A slight weight loss of about $4 \mathrm{wt} \%$ which occurs below $300{ }^{\circ} \mathrm{C}$ is ascribed to the removal of adsorbed and crystalline water. The followed weight loss is caused by the oxidation of $\mathrm{rGO}$ into $\mathrm{CO}_{2}$ and the decomposition of $\mathrm{MnO}_{2}$ into $\mathrm{Mn}_{2} \mathrm{O}_{3}$. Based on the residual mass of $\mathrm{Mn}_{2} \mathrm{O}_{3}$, the mass percentages of $\mathrm{MnO}_{2}$ in $\mathrm{MnO}_{2} @ \mathrm{rGO}$ composite was estimated to $\sim 9 \mathrm{wt} \% .{ }^{36}$ In addition to the TGA analysis, the $\mathrm{Mn}$ content of the $\mathrm{MnO}_{2} @ \mathrm{rGO}$ was determined to be $4.88 \mathrm{wt} \%$ (the content of $\mathrm{MnO}_{2}$ was $\sim 8$ $\mathrm{wt} \%$ ) by ICP-MS analyses after dissolving the sample in $35 \mathrm{wt} \% \mathrm{HCl}$.

As shown in Figure 3, the nitrogen adsorption-desorption isotherms of rGO and $\mathrm{MnO}_{2} @ \mathrm{rGO}$ resemble a type II adsorption isotherms, which indicates a wider distribution of pore diameters. ${ }^{37}$ The corresponding BET (Brunauer-Emmett-Teller) specific surface area for rGO and $\mathrm{MnO}_{2} @ \mathrm{rGO}$ were calculated to be $317 \mathrm{~m}^{2} \mathrm{~g}^{-1}$ and $186 \mathrm{~m}^{2} \mathrm{~g}^{-1}$. The porous structure provides sufficient space for the deposition of discharge products and facilitate the rapid transport of $\mathrm{O}_{2}$ and $\mathrm{Li}^{+} \cdot{ }^{38}$ Moreover, the high specific area contributes to a large catalytic active region with high number of exposed $\mathrm{MnO}_{2}$ active sites. 


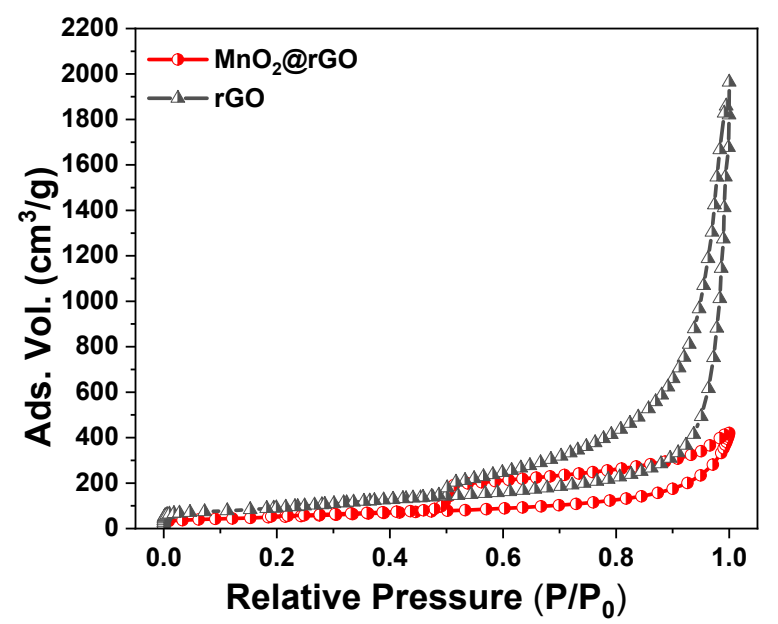

Figure 3. $\mathrm{N}_{2}$ adsorption-desorption isotherms of rGO and $\mathrm{MnO}_{2} @ \mathrm{rGO}$.

XRD measurements were carried out to characterize the crystallinity and phase purity of the samples. Both rGO and $\mathrm{MnO}_{2} @ \mathrm{rGO}$ samples possess two broad diffraction reflections $\left(9.2^{\circ}\right.$ and $15.3^{\circ}$ ) in XRD patterns (Figure $4 \mathrm{a}$ ). These reflections are similar to those observed for highly disordered graphitic structures. The d-spacing of the first diffraction corresponds to the (002) reflection of graphite and therefore most likely originates from small domains of stacked rGO sheets. The first diffraction position yields a mean inter graphene spacing of $0.35 \mathrm{~nm}$, which is substantially larger than that of graphite $(\mathrm{c} / 2=0.3354 \mathrm{~nm})$. The XRD pattern of $\mathrm{MnO}_{2} @ \mathrm{rGO}$ shows an additional broad and weak diffraction peak at about $7.6^{\circ}$, which could be assigned to the (101) crystal plane of $\mathrm{MnO}_{2}$ (JCPDS Number: 39-0375). However, due to the presence of just a single broad diffraction signal a clear crystallographic assignment is not possible. Nevertheless, the weak and broad peak confirms to the low amount of deposited manganese oxide and a rather small particle size (smaller than $20 \mathrm{~nm}$ ).

Raman spectroscopy was applied to further investigate the structural evolution of the $\mathrm{MnO}_{2} @ \mathrm{rGO}$, rGO and $\mathrm{MnO}_{2}$ samples (Figure 4b). Raman spectra of $\mathrm{MnO}_{2} @ \mathrm{rGO}$ and rGO specimens both have the typical bands of carbon materials, which are located at $1335 \mathrm{~cm}^{-1}$ (D-band) and $1592 \mathrm{~cm}^{-1}$ (G- 
band). ${ }^{39}$ The two peaks are composed of four bands: D1, D3, D4 and G. The G-band is assigned to the $\mathrm{E}_{2 \mathrm{~g}}$ phonon of $\mathrm{sp}^{2}$-bonded carbon atoms, which is a characteristic feature of graphitic layers. ${ }^{40,41}$ The D1-band is assigned to the breathing mode of $\kappa$-point phonons with $\mathrm{A}_{\mathrm{lg}}$ symmetry, which corresponds to disordered carbon or defective graphitic structures. ${ }^{40,41}$ The D3 peak shows the existence of fragments or functional groups in the amorphous phase which may also change the $\mathrm{C}-\mathrm{C}$ and $\mathrm{C}=\mathrm{C}$ stretching vibrations of the polyene-like structure (D4). ${ }^{41}$ The area ratio of $\mathrm{G}$ band and D1 band (named as $I_{G} / I_{D}$ ) is generally used as an indicator for the graphitization degree of carbon materials. The $\mathrm{I}_{\mathrm{G}} / \mathrm{I}_{\mathrm{D}}$ value is 0.37 and 0.30 for $\mathrm{rGO}$ and $\mathrm{MnO}_{2} @ \mathrm{rGO}$, respectively. This indicates a rather low graphitization degree of both samples. In addition to the G-band and D-band, $\mathrm{MnO}_{2} @ \mathrm{rGO}$ sample also presents a distinct band at around $650 \mathrm{~cm}^{-1}$, which corresponds to the symmetric stretching vibration $\mathrm{M}-\mathrm{O}$ of $\left[\mathrm{MnO}_{6}\right]$ groups. ${ }^{42}$
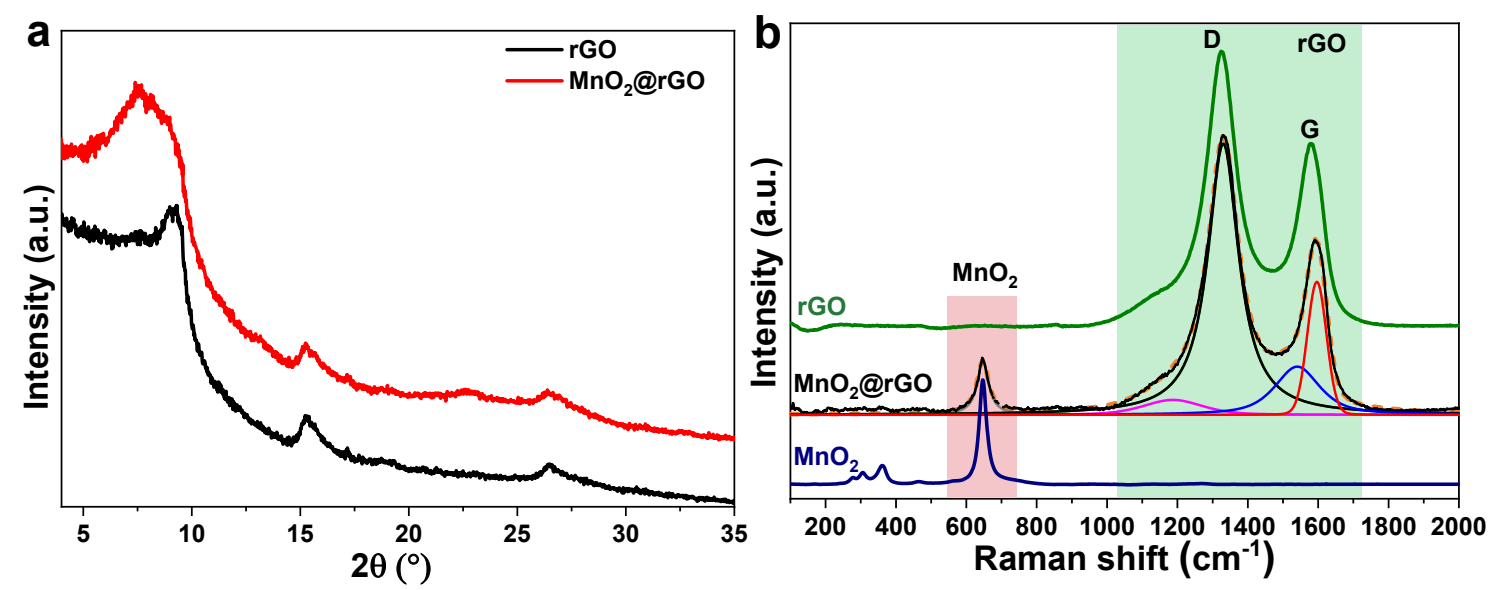

Figure 4. (a) XRD ( $\lambda=0.559407 \AA$ ) patterns of rGO and $\mathrm{MnO}_{2} @ \mathrm{rGO}$. (b) Raman spectra of rGO, $\mathrm{MnO}_{2}$ and $\mathrm{MnO}_{2} @ \mathrm{rGO}$.

XPS analysis was applied to determine the oxidation state and elemental composition of the prepared $\mathrm{MnO}_{2} @ \mathrm{rGO}$. Figure. S2 shows a survey scan of $\mathrm{MnO}_{2} @ \mathrm{rGO}$ which verifies the presence of the elements $\mathrm{Mn}, \mathrm{O}$ and $\mathrm{C}$. The high-resolution $\mathrm{Mn}$ 3s spectrum shows two peaks with a separation of $5.2 \mathrm{eV}$ due to spin-orbit splitting (Figure 5a). This value lies between the spin-orbit 
splitting for $\mathrm{Mn}^{4+}$ and $\mathrm{Mn}^{3+}$ of 4.6 and $5.5 \mathrm{eV}$, respectively, indicating the presence of both oxidation states. The high-resolution $M n 2 p_{3 / 2}$ spectrum was further explored to confirm this conclusion (Figure 5b). The absence of a shake-up satellite, which is typical for $\mathrm{Mn}^{2+}$ at $\sim 646 \mathrm{eV}$, confirms the absence of $\mathrm{Mn}^{2+}$ in the sample. The multiplet fitting approach of Biesinger et al. was applied here and adapted as in the work of Azmi et al. ${ }^{43,44}$ Two multiplets could be evidenced, which supports the presence of manganese in the oxidation state of $\mathrm{Mn}^{4+}$ and $\mathrm{Mn}^{3+}$ with a slightly higher concentration of $\mathrm{Mn}^{3+}\left(\mathrm{Mn}^{3+}: \mathrm{Mn}^{4+}=3: 2\right)$.

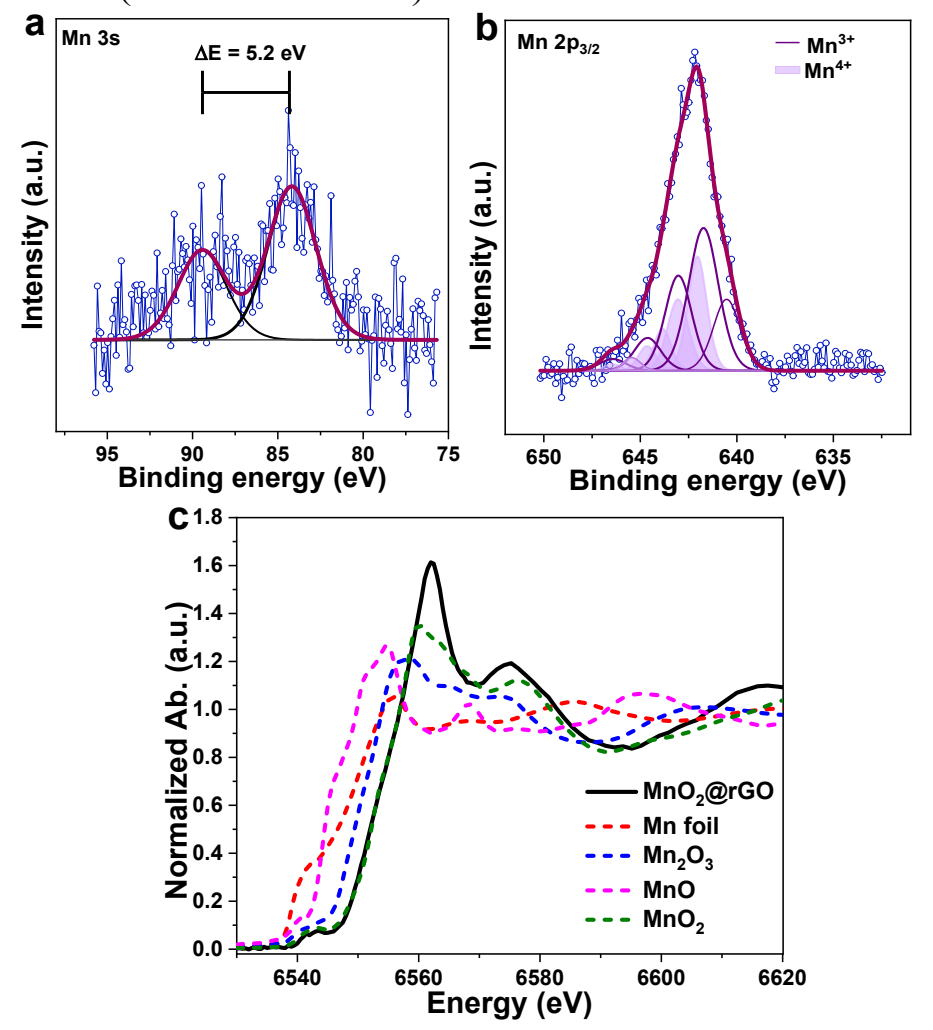

Figure 5. High-resolution $\mathrm{Mn} \mathrm{3s}$ (a) and $\mathrm{Mn} 2 \mathrm{p}_{3 / 2}$ (b) XPS spectra for $\mathrm{MnO}_{2} @ \mathrm{rGO}$; (c) Normalized Mn K-edge XANES spectra of the obtained $\mathrm{MnO}_{2} @ \mathrm{rGO}$ materials together with reference spectra of $\mathrm{Mn}$ foil, $\mathrm{MnO}, \mathrm{Mn}_{2} \mathrm{O}_{3}$ and $\mathrm{MnO}_{2}$.

Since the information depth for XPS is only a few nanometers, we employed XANES spectroscopy to obtain more detailed information about the electronic structure of the bulk. Mn K-edge position of the $\mathrm{MnO}_{2} @ \mathrm{rGO}$ composite overlaps with that of standard $\mathrm{MnO}_{2}$ (Figure 5c), which indicates 
the rGO based battery shows poor capacity retention with a continuous decay after the first cycle. Also the charging voltage of the rGO based battery continues to increase from the first to the fifteenth cycle. Moreover, the presence of trace water leads to an increase of discharge capacity for the $\mathrm{MnO}_{2} @ \mathrm{rGO}$ based battery (Figure. S4.) Meanwhile, the discharge voltage plateau is also slightly increased. This is because water is a strong Lewis acid and increases the solubility of $\mathrm{LiO}_{2}$ in the electrolyte solution. ${ }^{31}$ Therefore, the surface mechanism for the formation of discharge products is converted into a solution based mechanism. ${ }^{31}$ To test the rate capability galvanotatic cycling experiment at current densities from 100-800 $\mathrm{mAh} \mathrm{g}^{-1}$ where carried out (Figure $6 \mathrm{~b}$ ). The discharge capacity of the $\mathrm{MnO}_{2} @ \mathrm{rGO}$ based battery decreases with the cycling rate but is still capable to deliver a fairly high discharge capacity of $2025 \mathrm{~mA} \mathrm{~h} \mathrm{~g}^{-1}$ at a current density of $800 \mathrm{~mA}$ $\mathrm{g}^{-1}$

The voltage profiles during the first discharge-charge of the rGO and $\mathrm{MnO}_{2} @ \mathrm{rGO}$ based Li- $\mathrm{O}_{2}$ batteries are displayed in Figure 6c. The $\mathrm{MnO}_{2} @ \mathrm{rGO}$ based $\mathrm{Li}-\mathrm{O}_{2}$ battery shows a $0.2 \mathrm{~V}$ lower charge voltage compared to the rGO based battery. Hence, the lower charge voltage can be attributed to the catalytic effect of $\mathrm{MnO}_{2}$ for the OER process. ${ }^{7,45}$ The $\mathrm{MnO}_{2} @$ rGO based battery delivers an initial discharge capacity of $5139 \mathrm{mAh} \mathrm{g}^{-1}$. Even after the fifteenth cycle a discharge capacity of $4262 \mathrm{mAh} \mathrm{g}^{-1}$ is still obtained (Figure 6d). This corresponds to a capacity retention of about $80 \%$ after 15 cycles.

When compared to some selected important works related to the use of metal/metal oxide catalysts in $\mathrm{Li}-\mathrm{O}_{2}$ batteries, $\mathrm{MnO}_{2} @ \mathrm{rGO}$ exhibits a higher discharge capacity or capacity retention (Table 1) although it has a much lower catalyst content loading. For instance, in comparison to the $\mathrm{NiO} / \mathrm{rGO}$ composite described by $\mathrm{H}$. Wang et al, which has a similar catalyst content, our 
$\mathrm{MnO}_{2} @ \mathrm{rGO}$ based battery presents much higher capacity ( 4 times higher) and capacity retention. ${ }^{27}$ There are also some reported works $\left(\mathrm{MnO}_{2} / \mathrm{HPC}, \delta-\mathrm{MnO}_{2} @ \mathrm{MWCNTs}\right.$ and $\mathrm{Fe}_{2} \mathrm{O}_{3} / \mathrm{CNT}$ ) showing better performance. ${ }^{21,46,47}$ However, the catalyst content of these materials $(46,34$, and $75 \% \mathrm{wt} \%)$ is much higher than that of our material $(9 \mathrm{wt} \%)$. In addition, the synthesis process of the HPC (hierarchically porous carbon) template is complex, and the electrolyte used in the work about the $\delta-\mathrm{MnO}_{2} @$ MWCNTs based Li- $\mathrm{O}_{2}$ battery is special and complex. ${ }^{21,46}$ The $\mathrm{Fe}_{2} \mathrm{O}_{3} / \mathrm{CNT}$ based Li-O $\mathrm{O}_{2}$ batteries present longer cycle life and higher capacity retention, but the capacity is much lower than that of our battery (4 5 times lower). ${ }^{47}$ The pure rGO based battery presents a maximum discharge capacity of $4866 \mathrm{mAh} \mathrm{g}^{-1}$ and a discharge capacity of $2597 \mathrm{mAh}$ $\mathrm{g}^{-1}(53 \%$ capacity retention) after 15 cycles (Figure $6 \mathrm{~d})$. This value is much lower than the capacity retention of the $\mathrm{MnO}_{2} @$ rGO based battery. This demonstrates that the $\mathrm{MnO}_{2}$ nanoparticles effectively support the OER and hence restrain the accumulation of discharge products at the electrode surface. The good catalytic activity of the $\mathrm{MnO}_{2}$ particles may be attributed to their small particle size and high number of oxygen vacancies at their surface.
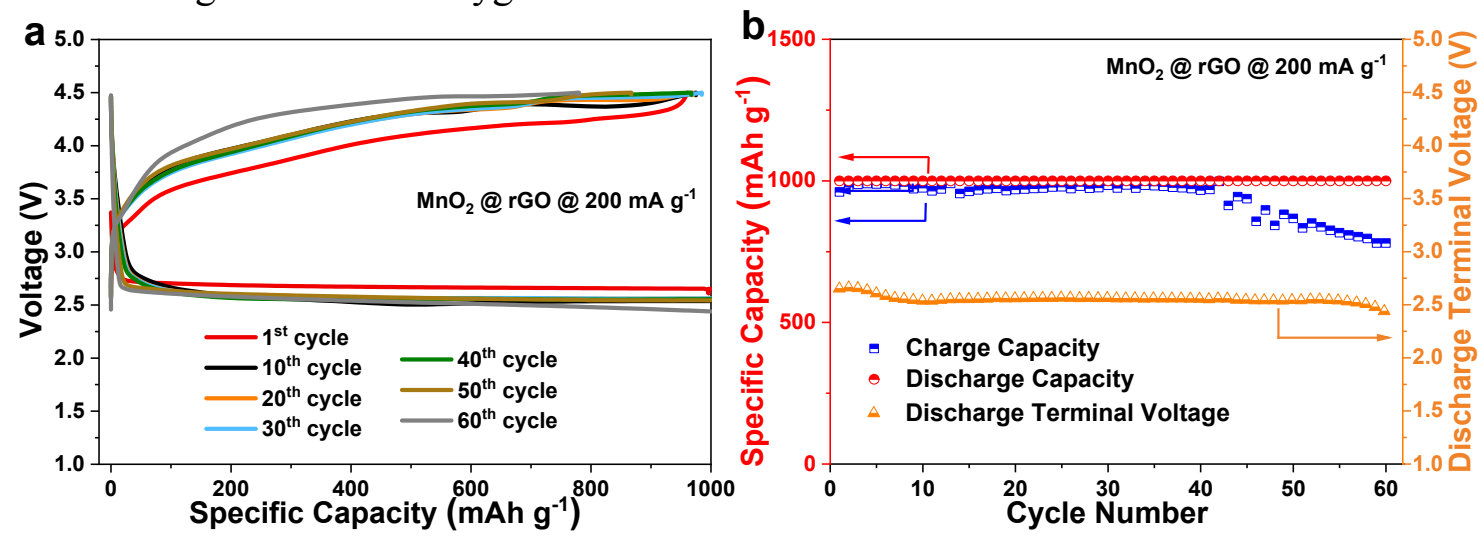

Figure 7. (a) Charge and discharge profiles of $\mathrm{MnO}_{2} @ \mathrm{rGO}$ at the $1^{\text {st }}, 10^{\text {th }}, 20^{\text {th }}, 30^{\text {th }}, 40^{\text {th }}, 50^{\text {th }}$ and $60^{\text {th }}$ cycles with a specific capacity limit of $1000 \mathrm{mAh} \mathrm{g}^{-1}$ at a current density of $200 \mathrm{~mA} \mathrm{~g}^{-1}$. (b) Discharge/charge capacity and discharge terminal voltage vs. cycle number at a current density of $200 \mathrm{~mA} \mathrm{~g}^{-1}$. 
Table 1. Selected works related to the use of Metal/Metal oxides as catalysts in $\mathrm{Li}-\mathrm{O}_{2}$ cells.

\begin{tabular}{|c|c|c|c|c|c|c|c|}
\hline Catalysts & $\begin{array}{l}\text { Content } \\
\left(\mathrm{wt}^{\mathrm{0}} \%\right)\end{array}$ & Electrolyte & $\begin{array}{l}\text { Initial capacity } \\
\left(\mathrm{mAh} \mathrm{g}^{-1} \text { cathode }\right)\end{array}$ & $\begin{array}{l}\text { Cycle } \\
\text { Num. }\end{array}$ & $\begin{array}{l}\text { End capacity } \\
\left(\mathrm{mAh} \mathrm{g}^{-1} \text { cathode }\right)\end{array}$ & $\begin{array}{l}\text { Capacity } \\
\text { retention }(\%)\end{array}$ & Ref. \\
\hline $\mathrm{NiO} / \mathrm{rGO}$ & 8 & $1 \mathrm{M}$ LiTFSI in TEGDME & 1023 & 10 & 697 & 68 & 27 \\
\hline $\mathrm{MnO}_{2} / \mathrm{HPC}$ & 46 & $1 \mathrm{M}$ LiTFSI in TEGDME & 5000 & 60 & 2000 & 40 & 21 \\
\hline MoSSe & 100 & $1 \mathrm{M} \mathrm{LiClO}_{4}$ in $\mathrm{DMSO}$ & 708 & 30 & 725 & 102 & 48 \\
\hline $\begin{array}{l}\delta-\mathrm{MnO}_{2} @ \\
\text { MWCNTs }\end{array}$ & 34 & $\begin{array}{c}0.8 / 0.5 \mathrm{M} \mathrm{LiTFSI} \mathrm{LiNO}_{3} \\
\text { in PYR14TFSI/DMSO }\end{array}$ & 28517 & & & & 46 \\
\hline $\mathrm{Fe}_{2} \mathrm{O}_{3} / \mathrm{CNT}$ & 75 & $\begin{array}{l}0.5 \mathrm{M} \text { LiTFSI in } \\
\text { TEGDME }\end{array}$ & 951 & 50 & 1295 & 136 & 47 \\
\hline $\mathrm{CNF@Pt}$ & 50 & $1 \mathrm{M} \mathrm{LiNO}_{3}$ in DMAc & 2955 & 24 & 1138 & 39 & 49 \\
\hline $\begin{array}{c}\text { Graphene/ } \\
\alpha-\mathrm{MnO}_{2}\end{array}$ & 50 & $\begin{array}{c}1 \mathrm{M} \mathrm{LiPF}_{6} \text { in NMP with } \\
\mathrm{PeO} / \mathrm{Al}_{2} \mathrm{O}_{3} \\
(0.05 \mathrm{M} / 0.01 \mathrm{M})\end{array}$ & 2850 & 10 & 1000 & 35 & 50 \\
\hline $\mathrm{NiCo}_{2} \mathrm{O}_{4}$ & 30 & $1 \mathrm{M}$ LiTFSI in TEGDME & 4386 & 3 & 3552 & 81 & 51 \\
\hline $\mathrm{CoO} / \mathrm{C}$ & 45 & $1 \mathrm{M}$ LiTFSI in TEGDME & 3132 & 8 & 1999 & 64 & 52 \\
\hline $\begin{array}{l}\mathrm{Co} / \mathrm{Mn} / \mathrm{O} \\
\text { Nanocube }\end{array}$ & 44 & $1 \mathrm{M}$ LiTFSI in TEGDME & 3836 & 5 & 2072 & 53 & 53 \\
\hline $\mathrm{IrO}_{2} / \mathrm{MnO}_{2}$ & 100 & $1 \mathrm{M} \mathrm{LiClO}_{4}$ in TEGDME & 2600 & 247 & 701 & 27 & 54 \\
\hline $\mathrm{CoMn}_{2} \mathrm{O}_{4}$ & 44 & $\begin{array}{l}0.5 \mathrm{M} \text { LiTFSI in } \\
\text { TEGDME }\end{array}$ & 3255 & 15 & 1667 & 51 & 55 \\
\hline $\mathrm{Mn}_{3} \mathrm{O}_{4} / \mathrm{RGO}$ & 80 & $0.1 \mathrm{M} \mathrm{LiPF}_{6}$ in DME & 2300 & 20 & 920 & 40 & 7 \\
\hline $\begin{array}{l}\text { Low-valent } \\
\mathrm{Mn}_{3} \mathrm{O}_{4} / \mathrm{RGO}\end{array}$ & 47 & $1 \mathrm{M}$ LiTFSI in TEGDME & 4500 & & & & 23 \\
\hline $\mathrm{C} / \alpha-\mathrm{MnO}_{2}$ & 10 & $1 \mathrm{M}$ LiTFSI in TEGDME & 1400 & 10 & 500 & 36 & 18 \\
\hline $\mathrm{rGO}-\mathrm{Ni}_{3} \mathrm{Pd}_{7}$ & 33 & $0.1 \mathrm{M} \mathrm{LiPF}_{6}$ in DMSO & 2512 & 10 & 750 & 30 & 56 \\
\hline $\mathrm{CoFe}_{2} \mathrm{O}_{4}$ & 16 & $0.1 \mathrm{M} \mathrm{LiPF}_{6}$ in $\mathrm{DMSO}$ & 7510 & 10 & 500 & 7 & 57 \\
\hline $\mathrm{rGO}-\mathrm{Co}_{48} \mathrm{Pt}_{52}$ & 33 & $0.5 \mathrm{M} \mathrm{LiPF}_{6}$ in DMSO & 9896 & 4 & 6000 & 61 & 58 \\
\hline This work & 9 & $\begin{array}{l}0.25 \mathrm{M} \text { LiTFSI in } \\
\text { TEGDME }\end{array}$ & 5139 & 15 & 4262 & 83 & \\
\hline
\end{tabular}


The cycling stability of the $\mathrm{MnO}_{2} @$ rGO based battery was further explored by galvanostatic cycling at a current density of $200 \mathrm{~mA} \mathrm{~g}^{-1}$ and a cut-off capacity of $1000 \mathrm{mAh} \mathrm{g}^{-1}$. Batteries based on $\mathrm{MnO}_{2} @ \mathrm{rGO}$ showed a constant discharge capacity over 60 cycles (Figure 7a). During the first seven cycles the discharge end voltage decays slightly from $2.65 \mathrm{~V}$ to $2.55 \mathrm{~V}$ and then keeps stable at $2.55 \mathrm{~V}$ until the 60 th cycle (Figure $7 \mathrm{~b}$ ).
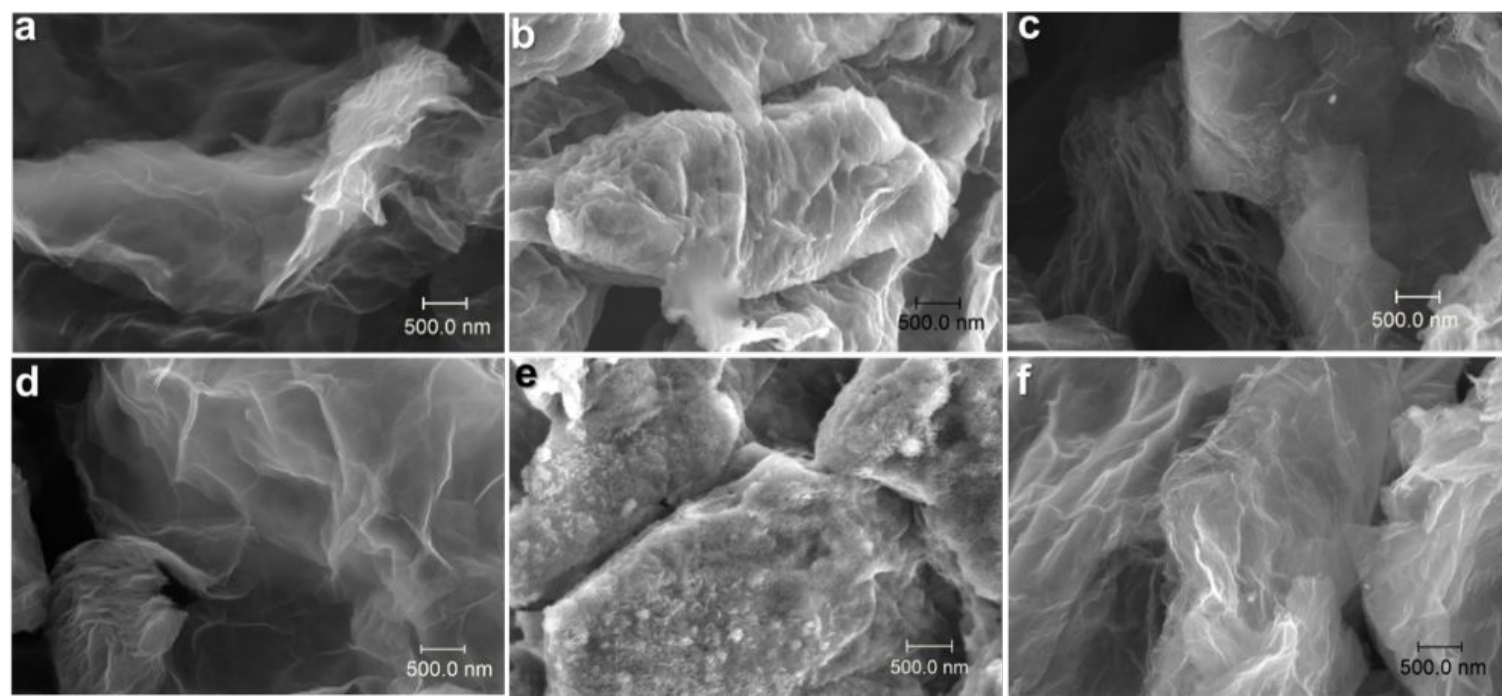

Figure 8. SEM images of pristine rGO electrode (a), after full discharge to $2.3 \mathrm{~V}(\mathrm{~b})$, and recharge to $4.5 \mathrm{~V}$ (c); SEM images of pristine $\mathrm{MnO}_{2} @ \mathrm{rGO}$ electrode (d), after full discharge to $2.3 \mathrm{~V}$ (e), and recharge to $4.5 \mathrm{~V}(\mathrm{f})$;

The morphologies of the discharge products were investigated by SEM. SEM images of the pristine $\mathrm{MnO}_{2} @ \mathrm{rGO}$ electrode, after the first discharge to $2.3 \mathrm{~V}$ and after recharge to $4.5 \mathrm{~V}$ are shown in Figure 8. After discharge to $2.3 \mathrm{~V}$, the porous multilayer structure of the $\mathrm{MnO}_{2} @ \mathrm{rGO}$ electrode is covered with a fine grained mossy deposition product (Figure 8e). After recharging to 4.5 $\mathrm{V}$, the discharge products disappear and the original multilayer porous structure of $\mathrm{MnO}_{2} @ \mathrm{rGO}$ becomes visible again (Figure 8f). In contrast, the discharge products on the pure rGO electrode form a smooth film, which covers the electrode surface (Figure $8 \mathrm{~b}$ ). This film possibly obstructs the free transportation of electrolyte, oxygen, and electrons, leading to the 
reduced capacity of pure rGO. Moreover, the discharged $\mathrm{MnO}_{2} @ \mathrm{rGO}$ electrode cycled without water shows smaller grained mossy deposits when compared to the discharge products of $\mathrm{MnO}_{2} @ \mathrm{rGO}$ cycled with trace water (Figure S5). Since $\mathrm{O}_{2}$ supply is unlimited, the capacity limitation of $\mathrm{Li}-\mathrm{O}_{2}$ batteries highly depend on availability of catalytic active sites. This means that the capacity is limited by the occupation of catalytic active sites by the deposition of discharge products. Thus, the morphology of deposited discharge products during discharge is closely related to discharge capacity. ${ }^{31}$ The very small grained mossy deposition will huddle together and leave limited space for oxygen and ion to diffuse to active sites.

Based on these SEM results, we conclude that the mass transport of $\mathrm{LiO}_{2}$ species is enhanced by $\mathrm{MnO}_{2}$. This enhancement may be attributed to the weakening of bindings between the intermediate $\left(\mathrm{LiO}_{2}\right.$ species) and the substrate by $\mathrm{MnO}_{2} \cdot{ }^{21}$ Moreover, the large exposed surface of the $\mathrm{MnO}_{2}$ nano-particles will lead to a higher interfacial current density, which reduces the reaction time to form discharged products. The enhancement of surface transport and the reduction of reaction time act together synergistically and lead to the formation of a fine grained and uniform discharge product. ${ }^{21}$

To identify the crystalline discharge products, XRD with Co radiation was applied. The XRD pattern clearly demonstrates that peaks corresponding to $\mathrm{LiOH}$ emerge after the discharge process (Figure 9b and S6). These peaks completely disappear in the subsequent charge process (Figure 9b), which indicates a complete decomposition of $\mathrm{LiOH}$. Furthermore, the phase purity of the discharge products was studied by Rietveld refinement. Figure 9a confirms that the main reflections are in good agreement with the tetragonal phase of LiOH (space group: P4/nmm (129)). Satisfactory agreement factors $\left(\mathrm{R}_{\mathrm{wp}}=2.4 \%, \mathrm{R}_{\mathrm{p}}=1.7 \%\right)$ with the cell parameter $a=b=3.5487(1)$ 
$\AA, c=4.3511(1) \AA, \alpha=\beta=\gamma=90^{\circ}$, and cell volume $=54.795(3) \AA^{3}$ are determined in this crystal refinement.
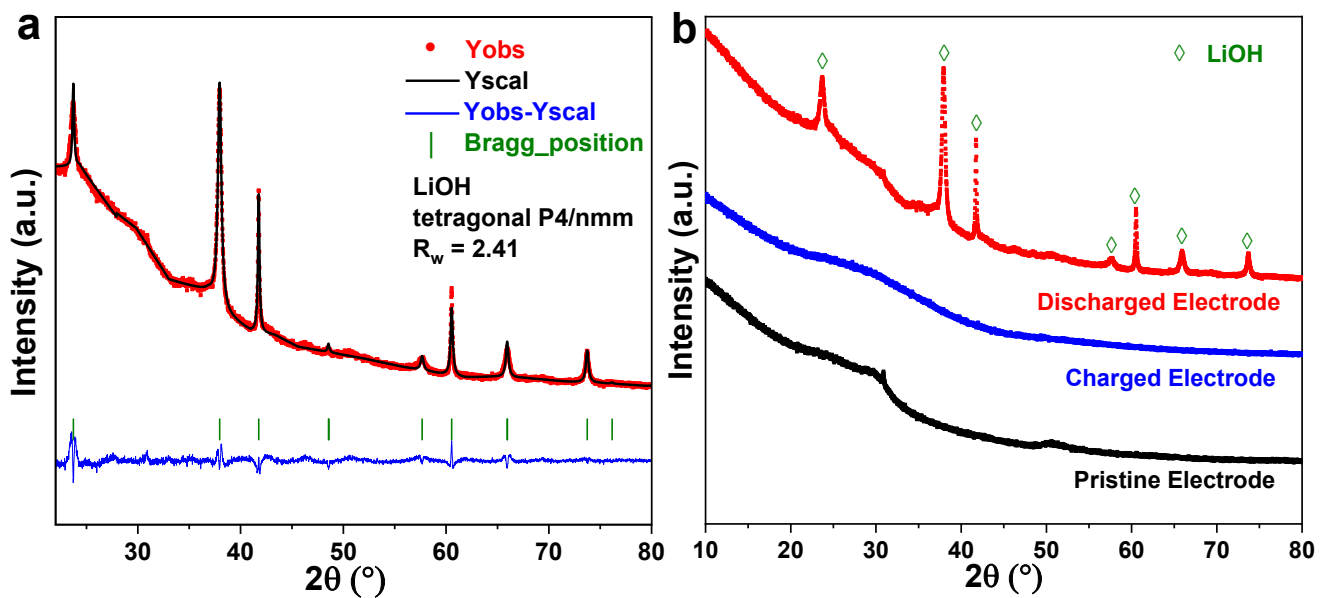

Figure 9. Rietveld refinement of the proposed $\mathrm{LiOH}$ structure model based on the XRD $(\lambda=1.78896 \AA)$ of discharged $\mathrm{MnO}_{2} @ \mathrm{rGO}$ electrode (a), XRD patterns of pristine $\mathrm{MnO}_{2} @ \mathrm{rGO}$ electrode, after discharge to $2.3 \mathrm{~V}$ and recharge to $4.5 \mathrm{~V}$ (b).

To further elucidate the nature of the discharge products, Raman measurements were carried out. The pristine electrode shows only the characteristic bands of $\mathrm{rGO}$ and $\mathrm{MnO}_{2}$. After discharge to $2.3 \mathrm{~V}$ the appearance of new bands indicates the formation of discharge products (Figure 10a). These bands disappear again after charge (Figure 10a), indicating a reversible and almost complete decomposition of the discharge products. Most changes in the Raman spectrum of the discharged electrode occur in the range between 300 and $750 \mathrm{~cm}^{-1}$. Despite some overlap, seven different bands labeled A, B, C, D, E, F and G can be distinguished in the enlarged view of this region (Figure 10b). The frequencies of the six bands labeled as B, C, D, E, F and G in Figure 10b are located at about 407, 431,501,566, 610 and $650 \mathrm{~cm}^{-1}$, which agrees well with the vibrational bands of $\mathrm{Li}_{2} \mathrm{MnO}_{3} .{ }^{59,60}$ Given the rather strong intensity of the $\mathrm{Li}_{2} \mathrm{MnO}_{3}$ bands if compared to the pristine sample and the small size of the original $\mathrm{MnO}_{2}$ particles, it seems most likely that $\mathrm{MnO}_{2}$ transforms into a lithiated manganese oxide during discharge. The Raman spectrum of the charged 
electrode reveals that this lithiated manganese oxide is transformed back into $\mathrm{MnO}_{2}$ again during charge. This transition between lithiated and non-lithiated manganese oxide may therefore at least be partially responsible for the catalytic activity of $\mathrm{MnO}_{2}$ in $\mathrm{Li}-\mathrm{O}_{2}$ batteries by reducing the electron transfer resistance and $\mathrm{O}_{2}$ desorption energy. ${ }^{61}$ The discharged electrode also shows another prominent band (labeled as A) at $320 \mathrm{~cm}^{-1}$ which can be attributed to $\mathrm{LiOH}$ (Figure 9b) based on referenc e measurements (Figure S7).
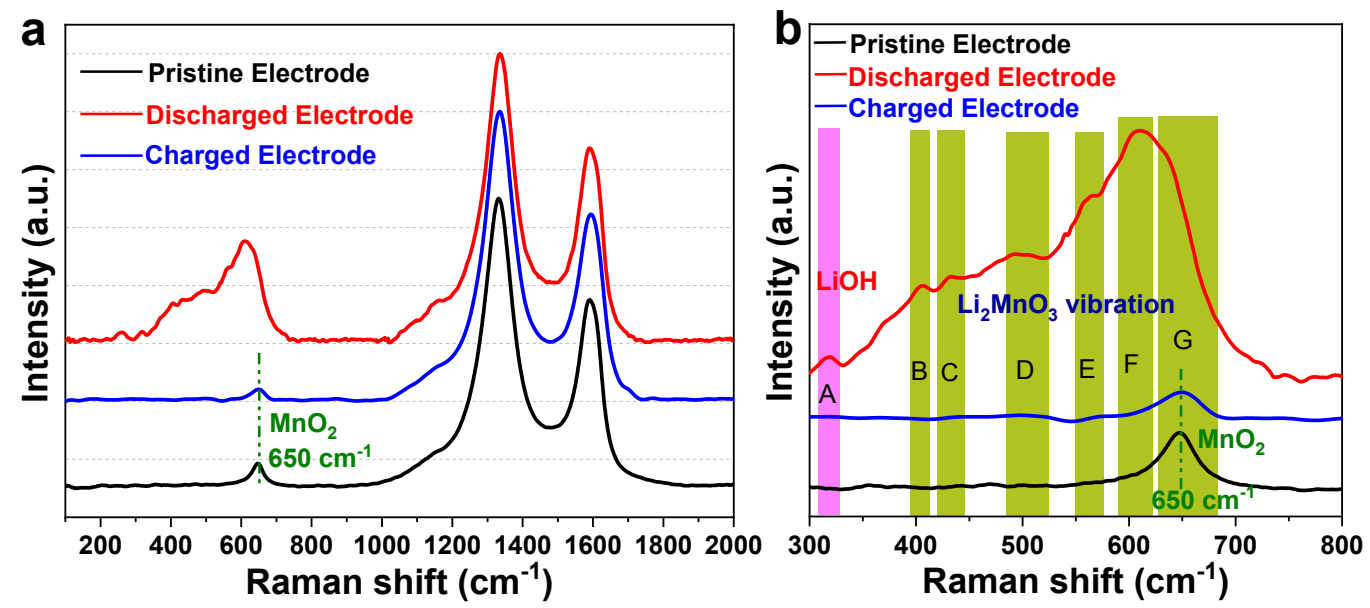

Figure 10. Raman spectra of pristine $\mathrm{MnO}_{2} @ \mathrm{rGO}$ electrode, after discharge to $2.3 \mathrm{~V}$ and recharge to $4.5 \mathrm{~V}$ (a). (b) The magnified Raman spectra in the range $300-800 \mathrm{~cm}^{-1}$ of pristine $\mathrm{MnO}_{2} @ \mathrm{rGO}$ electrode, after discharge to $2.3 \mathrm{~V}$ and recharge to $4.5 \mathrm{~V}$.

As outlined above, the Raman spectrum from rGO exhibits two distinct peaks located at $1335 \mathrm{~cm}^{-1}$ (D-bands) and $1592 \mathrm{~cm}^{-1}$ (G-bands). To study changes of the rGO during the discharge and charge process the Raman spectra in the range between $800-2000 \mathrm{~cm}^{-1}$ were deconvoluted into four component bands (D1, D3, D4 and G) (Figure $\mathrm{S} 8$ ). $\mathrm{I}_{\mathrm{D} 3} / \mathrm{I}_{\mathrm{T}}$ values were calculated from the area ratio of $\mathrm{D} 3$ band and the total integral intensity of all four bands $\left(\mathrm{I}_{\mathrm{T}}\right)$. This ratio reflects the amount of fragments or functional groups in amorphous phases. ${ }^{62} \mathrm{I}_{\mathrm{D} 3} / \mathrm{I}_{\mathrm{T}}$ values for both $\mathrm{rGO}$ and $\mathrm{MnO}_{2} @ \mathrm{rGO}$ electrodes increase after discharge. This indicates an increase of fragments or functional groups in the amorphous phase, which is ascribed to the side reactions during battery 
cycling with the electrolyte or the rGO itself. It can be seen that $\mathrm{I}_{\mathrm{D} 3} / \mathrm{I}_{\mathrm{T}}$ value of $\mathrm{rGO}$ electrode increases much more than that of the $\mathrm{MnO}_{2} @ \mathrm{rGO}$ electrode, indicating more side reactions for the rGO electrode. After charge, the $\mathrm{I}_{\mathrm{D} 3} / \mathrm{I}_{\mathrm{T}}$ value of $\mathrm{MnO}_{2} @ \mathrm{rGO}$ electrode decreases back to 0.12 , which indicates an almost complete removal of side products from electrode surface. In contrast, the $\mathrm{I}_{\mathrm{D} 3} / \mathrm{I}_{\mathrm{T}}$ value of rGO electrode after charge (0.14) stays elevated compared to its initial value (0.11). This suggests an incomplete removal of side products in case of the rGO electrode, which will result in a gradual accumulation of side products on the oxygen electrode and early cell death.

\section{CONCLUSION}

An $\mathrm{MnO}_{2} @ \mathrm{rGO}$ composite with a low amount of nano-sized $\mathrm{MnO}_{2}(9 \mathrm{wt} \%)$ uniformly deposited on the rGO surface has been synthesized and was investigated as oxygen electrode for $\mathrm{Li}^{-} \mathrm{O}_{2}$ batteries. Though the amount of $\mathrm{MnO}_{2}$ is very low in the composite, the composite still possesses a high catalytic activity. Batteries catalyzed by $\mathrm{MnO}_{2} @ \mathrm{rGO}$ delivered an initial discharge capacity of $5139 \mathrm{mAh} \mathrm{g}^{-1}$ and retained about $80 \%$ of their capacity (4262 $\left.\mathrm{mAh} \mathrm{g}^{-1}\right)$ after 15 full dischargecharge cycles at a current density of $100 \mathrm{~mA} \mathrm{~g}^{-1}$. Moreover, the charge voltage is reduced by 0.2 $\mathrm{V}$ compared to pure rGO based battery. The remarkable improvement of the electrochemical performance is due to the unique structure of $\mathrm{MnO}_{2} @ \mathrm{rGO}$ and the strong synergistic effect between the nanosized $\mathrm{MnO}_{2}$ particles and the rGO support. Firstly, the high rGO content assures a good electron conductivity, which facilitates electron transfer. Secondly, the 3D porous graphene frameworks made of multiple layers provides a matrix with high surface area for the deposition of discharge products. Thirdly, the porous structure also promises good transport properties for ionic and oxygen diffusion inside the electrode. Fourthly, the nano-sized $\mathrm{MnO}_{2}$ (smaller than $20 \mathrm{~nm}$ ) improves the catalytic activity of the surface which leads to higher interfacial current densities and 
shorter reaction times. Further, the surface transport of $\mathrm{Li}_{\mathrm{x}} \mathrm{O}_{2}$ species is enhanced by $\mathrm{MnO}_{2}$. Both aspects contribute to the formation of a thin film of uniformly distributed discharged products of small particle size, which can be easily decomposed during charge. Further, we found evidence for the reversible transition of manganese oxide into lithiated manganese oxide during discharge. This transition, which involves the incorporation of lithium and oxygen, seems to play an important role for the catalytic activity of $\mathrm{MnO}_{2}$ and hence the reduction of the electron transfer resistance of the OER.

\section{ASSOCIATED CONTENT}

\section{Supporting Information.}

The following files are available free of charge.

STEM and the corresponding elemental mapping of Manganese, Oxygen and Carbon images of the $\mathrm{MnO}_{2} @ \mathrm{rGO}$ XPS survey spectrum of the $\mathrm{MnO}_{2} @ \mathrm{rGO}$. Galvanostatic discharge-charge curves of rGO cycled at a current density of $100 \mathrm{~mA} \mathrm{~g}^{-1}$ between $2.3 \mathrm{~V}-4.5 \mathrm{~V}$. Galvanostatic discharge-charge curves of $\mathrm{MnO}_{2} @ \mathrm{rGO}$ cycled without water at a current density of 100 mA g-1 between 2.3 V-4.5 V. SEM images of $\mathrm{MnO}_{2} @ \mathrm{rGO}$ electrode after full discharge to $2.3 \mathrm{~V}$ with no water. XRD spectra of rGO electrode after discharge to $2.3 \mathrm{~V}$. Raman spectra of raw LiOH. Deconvoluted Raman spectra of the pristine $\mathrm{MnO}_{2} @ \mathrm{rGO}$ electrode, after discharge to $2.3 \mathrm{~V}$ and recharge to $4.5 \mathrm{~V}$ (PDF).

\section{AUTHOR INFORMATION}

\section{Corresponding Author}

*E-mail address: frieder.scheiba@kit.edu (F. Scheiba); Tel.:+49 72160828506 


\section{Notes}

There are no conflicts to declare.

\section{ACKNOWLEDGMENT}

This work was supported by the China Scholarship Council (CSC grant number: 20159969613). The work also got technical support from Udo Geckle (SEM measurement) and Dr. Dominique Mook ( $\mathrm{N}_{2}$ adsorption and desorption isotherms). We acknowledge the Deutsche ElektronenSyncrotron (DESY) in Hamburg, Germany, for provision of beam-time at the P65 beamline of the synchrotron radiation source Petra-III. We would like to thank Edmund Welter from Experiments Division in DESY, Hamburg. We acknowledge the KNMF for the provision of TEM and ICP-MS measurements. This work contributes to the research performed at CELEST (Center for Electrochemical Energy Storage Ulm-Karlsruhe).

\section{REFERENCES}

(1) Liu, T.; Leskes, M.; Yu, W.; Moore, A. J.; Zhou, L.; Bayley, P. M.; Kim, G.; Grey, C. P. Cycling Li-O 2 Batteries via LiOH Formation and Decomposition. Science 2015, 350, 530533.

(2) Zhao, G.; Mo, R.; Wang, B.; Zhang, L.; Sun, K. Enhanced Cyclability of Li-O ${ }_{2}$ Batteries $^{2}$ Based on $\mathrm{TiO}_{2}$ Supported Cathodes with No Carbon or Binder. Chem. Mater. 2014, 26, $2551-2556$.

(3) Xu, J.-J.; Wang, Z.-L.; Xu, D.; Meng, F.-Z.; Zhang, X.-B. 3D Ordered Macroporous $\mathrm{LaFeO}_{3}$ as Efficient Electrocatalyst for $\mathrm{Li}_{-} \mathrm{O}_{2}$ Batteries with Enhanced Rate Capability and Cyclic Performance. Energy Environ. Sci. 2014, 7 (7), 2213. 
(4) Ding, N.; Chien, S. W.; Hor, T. S. A.; Lum, R.; Zong, Y.; Liu, Z. Influence of Carbon Pore Size on the Discharge Capacity of $\mathrm{Li}_{-} \mathrm{O}_{2}$ Batteries. J. Mater. Chem. A 2014, 2 (31), 1243312441.

(5) Oh, S. H.; Black, R.; Pomerantseva, E.; Lee, J. H.; Nazar, L. F. Synthesis of a Metallic Mesoporous Pyrochlore as a Catalyst for Lithium- $\mathrm{O}_{2}$ Batteries. Nat. Chem. 2012, 4 (12), 1004-1010.

(6) Guo, Z.; Zhou, D.; Dong, X.; Qiu, Z.; Wang, Y.; Xia, Y. Ordered Hierarchical Mesoporous/Macroporous Carbon: A High-Performance Catalyst for Rechargeable Li-O 2 Batteries. Adv. Mater. 2013, 25 (39), 5668-5672.

(7) Li, Q.; Xu, P.; Zhang, B.; Tsai, H.; Wang, J.; Wang, H.-L.; Wu, G. One-Step Synthesis of $\mathrm{Mn}_{3} \mathrm{O}_{4} /$ Reduced Graphene Oxide Nanocomposites for Oxygen Reduction in Nonaqueous Li-O 2 Batteries. Chem. Commun. 2013, 49 (92), 10838.

(8) Zhu, L.; Gao, Q.; Tan, Y.; Tian, W.; Xu, J.; Yang, K.; Yang, C. Nitrogen and Oxygen CoDoped Microporous Carbons Derived from the Leaves of Euonymus Japonicas as High Performance Supercapacitor Electrode Material. Micropor. Mesopor. Mater. 2015, 210, 19.

(9) Zeng, F.; Pan, Y.; Yang, Y.; Li, Q.; Li, G.; Hou, Z.; Gu, G. Facile Construction of $\mathrm{Mn}_{3} \mathrm{O}_{4}$ $\mathrm{MnO}_{2}$ hetero-Nanorods/Graphene Nanocomposite for Highly Sensitive Electrochemical Detection of Hydrogen Peroxide. Electrochim. Acta 2016, 196, 587-596.

(10) Lu, Y.-C.; Gasteiger, H. A.; Crumlin, E.; McGuire, R.; Shao-Horn, Y. Electrocatalytic Activity Studies of Select Metal Surfaces and Implications in Li-Air Batteries. J. 
Electrochem. Soc. 2010, 157 (9), A1016-A1025.

(11) Ryu, W. H.; Yoon, T. H.; Song, S. H.; Jeon, S.; Park, Y. J.; Kim, I. D. Bifunctional Composite Catalysts Using $\mathrm{Co}_{3} \mathrm{O}_{4}$ Nanofibers Immobilized on Nonoxidized Graphene Nanoflakes for High-Capacity and Long-Cycle Li-O 2 Battery. Nano Lett. 2013, 13 (9), 4190-4197.

(12) Lei, Y.; Lu, J.; Luo, X.; Wu, T.; Du, P.; Zhang, X.; Ren, Y.; Wen, J.; Miller, D. J.; Miller, J. T. Synthesis of Porous Carbon Supported Palladium Nanoparticle Catalysts by Atomic Layer Deposition: Application for Rechargeable Lithium- $\mathrm{O}_{2}$ Battery. Nano Lett. 2013, 13 (9), 4182-4189.

(13) Xu, J.-J.; Xu, D.; Wang, Z.-L.; Wang, H.-G.; Zhang, L.-L.; Zhang, X.-B. Synthesis of Perovskite-Based Porous $\mathrm{La}_{0.75} \mathrm{Sr}_{0.25} \mathrm{MnO}_{3}$ Nanotubes as a Highly Efficient Electrocatalyst for Rechargeable Lithium-Oxygen Batteries. Angew. Chem. Int. Ed. 2013, 52 (14), 38873890.

(14) Lu, X.; Zhang, L.; Sun, X.; Si, W.; Yan, C.; Schmidt, O. G. Bifunctional Au-Pd Decorated $\mathrm{MnO}_{\mathrm{x}}$ Nanomembranes as Cathode Materials for $\mathrm{Li}-\mathrm{O}_{2}$ Batteries. J. Mater. Chem. A 2016, $4(11), 4155-4160$.

(15) Sun, N.; Liu, H.; Yu, Z.; Zheng, Z.; Shao, C. Mn-Doped $\mathrm{La}_{0.6} \mathrm{Sr}_{0.4} \mathrm{CoO}_{3}$ perovskite Catalysts with Enhanced Performances for Non-Aqueous Electrolyte Li- $\mathrm{O}_{2}$ Batteries. RSC Adv. 2016, 6(16), 13522-13530.

(16) Cao, Y.; Wei, Z.; He, J.; Zang, J.; Zhang, Q.; Zheng, M.; Dong, Q. $\alpha-\mathrm{MnO}_{2}$ nanorods Grown in Situ on Graphene as Catalysts for $\mathrm{Li}_{-} \mathrm{O}_{2}$ Batteries with Excellent Electrochemical 
Performance. Energy Environ. Sci. 2012, 5 (12), 9765-9768.

(17) Han, X.; Hu, Y.; Yang, J.; Cheng, F.; Chen, J. Porous Perovskite $\mathrm{CaMnO}_{3}$ as an Electrocatalyst for Rechargeable $\mathrm{Li}_{-} \mathrm{O}_{2}$ Batteries. Chem. Commun. 2014, 50 (12), $1497-$ 1499.

(18) Qin, Y.; Lu, J.; Du, P.; Chen, Z.; Ren, Y.; Wu, T.; Miller, J. T.; Wen, J.; Miller, D. J.; Zhang, Z. In Situ Fabrication of Porous-Carbon-Supported $\alpha-\mathrm{MnO}_{2}$ Nanorods at Room Temperature: Application for Rechargeable Li- $\mathrm{O}_{2}$ Batteries. Energy Environ. Sci. 2013, 6 (2), 519-531.

(19) Wang, H.; Yang, Y.; Liang, Y.; Zheng, G.; Li, Y.; Cui, Y.; Dai, H. Rechargeable Li-O ${ }_{2}$ Batteries with a Covalently Coupled $\mathrm{MnCo}_{2} \mathrm{O}_{4}$-Graphene Hybrid as an Oxygen Cathode Catalyst. Energy Environ. Sci. 2012, 5 (7), 7931-7935.

(20) Elmacı, G.; Ertürk, A. S.; Sevim, M.; Metin, Ö. $\mathrm{MnO}_{2}$ Nanowires Anchored on Mesoporous Graphitic Carbon Nitride $\left(\mathrm{MnO}_{2} @ m p g-\mathrm{C}_{3} \mathrm{~N}_{4}\right)$ as a Highly Efficient Electrocatalyst for the Oxygen Evolution Reaction. Int. J. Hydrogen Energy 2019, 4.

(21) Han, X.; Cheng, F.; Chen, C.; Hu, Y.; Chen, J. Uniform MnO2 Nanostructures Supported on Hierarchically Porous Carbon as Efficient Electrocatalysts for Rechargeable Li- $\mathrm{O}_{2}$ Batteries. Nano Res. 2014, 8 (1), 156-164.

(22) Gu, T.; Agyeman, D. A.; Shin, S.; Jin, X.; Lee, J. M. A - $\mathrm{MnO}_{2}$ Nanowire-Anchored Highly Oxidized Cluster as a Catalyst for $\mathrm{Li}_{-} \mathrm{O}_{2}$ Batteries : Superior Electrocatalytic Activity and High Functionality. Angew. Chem. Int. Ed. 2018, 57, 15984-15989. 
(23) Adpakpang, K.; Oh, S. M.; Agyeman, D. A.; Jin, X. Holey 2D Nanosheets of Low-Valent Manganese Oxides with an Excellent Oxygen Catalytic Activity and a High Functionality as a Catalyst for $\mathrm{Li}_{-} \mathrm{O}_{2}$ Batteries. Adv. Funct. Mater. 2018, 28, 1707106.

(24) Bi, R.; Liu, G.; Zeng, C.; Wang, X.; Zhang, L.; Qiao, S. 3D Hollow $\alpha-\mathrm{MnO}_{2}$ Framework as an Efficient Electrocatalyst for Lithium-Oxygen Batteries. Small 2019, 4, 1804958.

(25) Jian, Z.; Liu, P.; Li, F.; He, P.; Guo, X.; Chen, M.; Zhou, H. Core-Shell-Structured CNT@ $\mathrm{RuO}_{2}$ Composite as a High-Performance Cathode Catalyst for Rechargeable Li-O 2 Batteries. Angew. Chem. Int. Ed. 2014, 53 (2), 442-446.

(26) Gao, R.; Yang, Z.; Zheng, L.; Gu, L.; Liu, L.; Lee, Y. L.; Hu, Z.; Liu, X. Enhancing the Catalytic Activity of $\mathrm{Co}_{3} \mathrm{O}_{4}$ for $\mathrm{Li}-\mathrm{O}_{2}$ Battery through the Synergy of Surface/Interface/Doping Engineering. ACS Catal. 2018, 8, 1955-1963.

(27) Wang, H. Q.; Fan, X. P.; Zhang, X. H.; Huang, Y. G.; Wu, Q.; Pan, Q. C.; Li, Q. Y. In Situ Growth of $\mathrm{NiO}$ Nanoparticles on Carbon Paper as a Cathode for Rechargeable $\mathrm{Li}-\mathrm{O}_{2}$ Batteries. RSC Adv. 2017, 7 (38), 23328-23333.

(28) Yang, C.; Gao, Q.; Tian, W.; Tan, Y.; Zhang, T.; Yang, K.; Zhu, L. Superlow Load of Nanosized MnO on a Porous Carbon Matrix from Wood Fi Bre with Superior Lithium Ion Storage Performance. J. Mater. Chem. A 2014, 2, 19975-19982.

(29) Black, R.; Lee, J. H.; Adams, B.; Mims, C. a.; Nazar, L. F. The Role of Catalysts and Peroxide Oxidation in Lithium-Oxygen Batteries. Angew. Chem. Int. Ed. 2013, 52 (1), 392396. 
(30) Meini, S.; Piana, M.; Tsiouvaras, N.; Garsuch, A.; Gasteiger, H. A. The Effect of Water on the Discharge Capacity of a Non-Catalyzed Carbon Cathode for $\mathrm{Li}_{2} \mathrm{O}_{2}$ Batteries. Electrochem. Solid State Lett. 15 (4), A45-A48.

(31) Aetukuri, N. B.; McCloskey, B. D.; Garciá, J. M.; Krupp, L. E.; Viswanathan, V.; Luntz, A. C. Solvating Additives Drive Solution-Mediated Electrochemistry and Enhance Toroid Growth in Non-Aqueous Li-O 2 Batteries. Nat. Chem. 2015, 7 (1), 50-56.

(32) Tellgren, R. Neutron Powder Diffraction in Sweden. Phys. B 1985, 26 A, 55-69.

(33) K. L. Parry, A. G. Shard, R. D. Short, R. G. White, J. D. W. and A. W. ARXPS Characterisation of Plasma Polymerised Surface Chemical Gradients. Surf. Interface Anal. 2006, 38 (August), 1497-1504.

(34) Scofield, J. H. HARTREE-SLATER SUBSHELL PHOTOIONIZATION CROSSSECTIONS AT 1254 AND 1487 EV. J. Electron Spectrosc. 1976, 8, 129-137.

(35) Ravel, B.; Newville, M. ATHENA, ARTEMIS, HEPHAESTUS: Data Analysis for X-Ray Absorption Spectroscopy Using IFEFFIT. J. Synchrotron Rad. 2005, 12 (4), 537-541.

(36) Xin, G.; Wang, Y.; Zhang, J.; Jia, S.; Zang, J.; Wang, Y. A Self-Supporting Graphene/MnO 2 Composite for High-Performance Supercapacitors. Int. J. Hydrogen Energy. 2015, 40 (32), 10176-10184.

(37) Zhao, C. T.; Yu, C.; Liu, S. H.; Yang, J.; Fan, X. M.; Huang, H. W.; Qiu, J. 3D Porous NDoped Graphene Frameworks Made of Interconnected Nanocages for Ultrahigh-Rate and Long-Life Li-O 2 Batteries. Adv. Funct. Mater. 2015, 25 (44), 6913-6920. 
(38) Zhang, S.; Wen, Z.; Lu, Y.; Wu, X.; Yang, J. Highly Active Mixed-Valent $\mathrm{MnO}_{\mathrm{x}}$ Spheres Constructed by Nanocrystals as Efficient Catalysts for Long-Cycle Li-O $\mathrm{O}_{2}$ Batteries. J. Mater. Chem. A 2016, 4, 17129-17137.

(39) Tian, W.; Gao, Q.; Tan, Y.; Zhang, Y.; Xu, J.; Li, Z.; Yang, K.; Zhu, L.; Liu, Z. ThreeDimensional Functionalized Graphenes with Systematical Control over the Interconnected Pores and Surface Functional Groups for High Energy Performance Supercapacitors. Carbon 2015, 85, 351-362.

(40) Dresselhaus, M. S.; Dresselhaus, G.; Saito, R.; Jorio, A. Raman Spectroscopy of Carbon Nanotubes. Phys. Rep. 2005, 409 (2), 47-49.

(41) Ferrari, A. C. Raman Spectroscopy of Graphene and Graphite: Disorder, Electron-Phonon Coupling, Doping and Nonadiabatic Effects. Solid State Commun. 2007, 143 (1-2), 47-57.

(42) Wang, Y.; Guan, H.; Du, S.; Wang, Y. A Facile Hydrothermal Synthesis of $\mathrm{MnO}_{2} \mathrm{Nanorod}_{-}$ Reduced Graphene Oxide Nanocomposites Possessing Excellent Microwave Absorption Properties. RSC Adv. 2015, 5 (108), 88979-88988.

(43) Azmi, R.; Ulrich, S. Surface Analytical Approaches to Reliably Characterize Lithium Ion Battery Electrodes. Surf Interface Anal. 2017, 50 (September), 43-51.

(44) Biesinger, M. C.; Payne, B. P.; Grosvenor, A. P.; Lau, L. W. M.; Gerson, A. R.; St, R.; Smart, C. Resolving Surface Chemical States in XPS Analysis of First Row Transition Metals, Oxides and Hydroxides : Cr, Mn , Fe , Co and Ni. Appl. Surf. Sci. 2011, 257, 27172730. 
(45) Wang, F.; Wen, Z.; Shen, C.; Wu, X.; Liu, J. Synthesis of $\alpha-\mathrm{MnO}_{2}$ Nanowires Modified by $\mathrm{Co}_{3} \mathrm{O}_{4}$ Nanoparticles as a High-Performance Catalyst for Rechargeable Li- $\mathrm{O}_{2}$ Batteries. Phys. Chem. Chem. Phys. 2016, 18 (2), 926-931.

(46) Ma, L.; Meng, N.; Zhang, Y.; Lian, F. Improved Electrocatalytic Activity of $\delta-\mathrm{MnO}_{2} @$ MWCNTs by Inducing the Oriented Growth of Oxygen Reduction Products in $\mathrm{Li}-\mathrm{O}_{2}$ Batteries. Nano Energy 2019, 58 (December 2018), 508-516.

(47) Li, Z.; Ganapathy, S.; Xu, Y.; Zhu, Q.; Chen, W.; Kochetkov, I.; George, C.; Nazar, L. F.; Wagemaker, M. $\mathrm{Fe}_{2} \mathrm{O}_{3}$ Nanoparticle Seed Catalysts Enhance Cyclability on Deep (Dis)Charge in Aprotic $\mathrm{Li}_{2} \mathrm{O}_{2}$ Batteries. Adv. Energy Mater. 2018, 8, 1703513.

(48) Zhang, S.; Huang, Z.; Wen, Z.; Zhang, L.; Jin, J.; Shahbazian-Yassar, R.; Yang, J. Local Lattice Distortion Activate Metastable Metal Sulfide as Catalyst with Stable Full DischargeCharge Capability for Li-O 2 Batteries. Nano Lett. 2017, 17 (6), 3518-3526.

(49) Bui, H. T.; Kim, D. Y.; Kim, D. W.; Suk, J.; Kang, Y. Carbon Nanofiber@platinum by a Coaxial Electrospinning and Their Improved Electrochemical Performance as a $\mathrm{Li}-\mathrm{O}_{2}$ Battery Cathode. Carbon 2018, 130, 94-104.

(50) Cetinkaya, T.; Akbulut, H.; Tokur, M.; Ozcan, S.; Uysal, M. High Capacity Graphene/ $\alpha-$ $\mathrm{MnO}_{2}$ nanocomposite Cathodes for Li-o2 Batteries. Int. J. Hydrogen Energy. 2016, 41 (23), $9746-9754$.

(51) Sennu, P.; Park, H. S.; Park, K. U.; Aravindan, V.; Nahm, K. S.; Lee, Y. S. Formation of $\mathrm{NiCo}_{2} \mathrm{O}_{4}$ rods over $\mathrm{Co}_{3} \mathrm{O}_{4}$ nanosheets as Efficient Catalyst for $\mathrm{Li}-\mathrm{O}_{2}$ Batteries and Water Splitting. J. Catal. 2017, 349, 175-182. 
(52) Gao, R.; Li, Z.; Zhang, X.; Zhang, J.; Hu, Z.; Liu, X. Carbon-Dotted Defective CoO with Oxygen Vacancies: A Synergetic Design of Bifunctional Cathode Catalyst for $\mathrm{Li}-\mathrm{O}_{2}$ Batteries. ACS. Catal. 2016, 6 (1), 400-406.

(53) Zhang, J.; Wang, L.; Xu, L.; Ge, X.; Zhao, X.; Lai, M.; Liu, Z.; Chen, W. Porous CobaltManganese Oxide Nanocubes Derived from Metal Organic Frameworks as a Cathode Catalyst for Rechargeable Li-O 2 Batteries. Nanoscale 2015, 7 (2), 720-726.

(54) Tang, C.; Sun, P.; Xie, J.; Tang, Z.; Yang, Z.; Dong, Z. Two-Dimensional $\mathrm{IrO}_{2} / \mathrm{MnO}_{2}$ Enabling Conformal Growth of Amorphous. Energy Storage Mater. 2017, 9 (July), 206213.

(55) Sadighi, Z.; Huang, J.; Qin, L.; Yao, S.; Cui, J.; Kim, J. Positive Role of Oxygen Vacancy

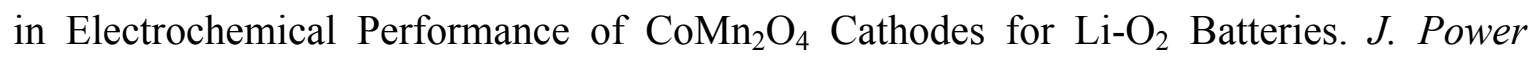
Sources 2017, 365, 134-147.

(56) Sevim, M.; Şener, T.; Metin, Ö. Monodisperse MPd (M: Co, Ni, Cu) Alloy Nanoparticles Supported on Reduced Graphene Oxide as Cathode Catalysts for the Lithium-Air Battery. Int. J. Hydrogen Energy 2015, 40 (34), 10876-10882.

(57) Şener, T.; Kayhan, E.; Sevim, M.; Metin, Ö. Monodisperse $\mathrm{CoFe}_{2} \mathrm{O}_{4}$ Nanoparticles Supported on Vulcan XC-72: High Performance Electrode Materials for Lithium-Air and Lithium-Ion Batteries. J. Power Sources 2015, 288, 36-41.

(58) Sevim, M.; Francia, C.; Amici, J.; Vankova, S.; Şener, T.; Metin, Ö. Bimetallic MPt (M: $\mathrm{Co}, \mathrm{Cu}, \mathrm{Ni}$ ) Alloy Nanoparticles Assembled on Reduced Graphene Oxide as High Performance Cathode Catalysts for Rechargable Lithium-Oxygen Batteries. J. Alloys 
Compd. 2016, 683, 231-240.

(59) Wu, Q.; Maroni, V. A.; Gosztola, D. J.; Miller, D. J.; Dees, D. W.; Lu, W. A Raman-Based Investigation of the Fate of $\mathrm{Li}_{2} \mathrm{MnO}_{3}$ in Lithium- and Manganese-Rich Cathode Materials for Lithium Ion Batteries. J. Electrochem. Soc. 2015, 162 (7), A1255-A1264.

(60) Ramana, C. V; Massot, M.; Julien, C. M. XPS and Raman Spectroscopic Characterization of $\mathrm{LiMn}_{2} \mathrm{O}_{4}$ Spinels. Surf. Interface Anal. 2020, 37, 412-16.

(61) Zhu, J.; Ren, X.; Liu, J.; Zhang, W.; Wen, Z. Unraveling the Catalytic Mechanism of $\mathrm{Co}_{3}$ $\mathrm{O}_{4}$ for the Oxygen Evolution Reaction in a Li-O 2 Battery. ACS Catal. 2015, 5 (1), 73-81.

(62) Sadezky, A.; Muckenhuber, H.; Grothe, H.; Niessner, R.; Pöschl, U. Raman Microspectroscopy of Soot and Related Carbonaceous Materials: Spectral Analysis and Structural Information. Carbon 2005, 43 (8), 1731-1742. 


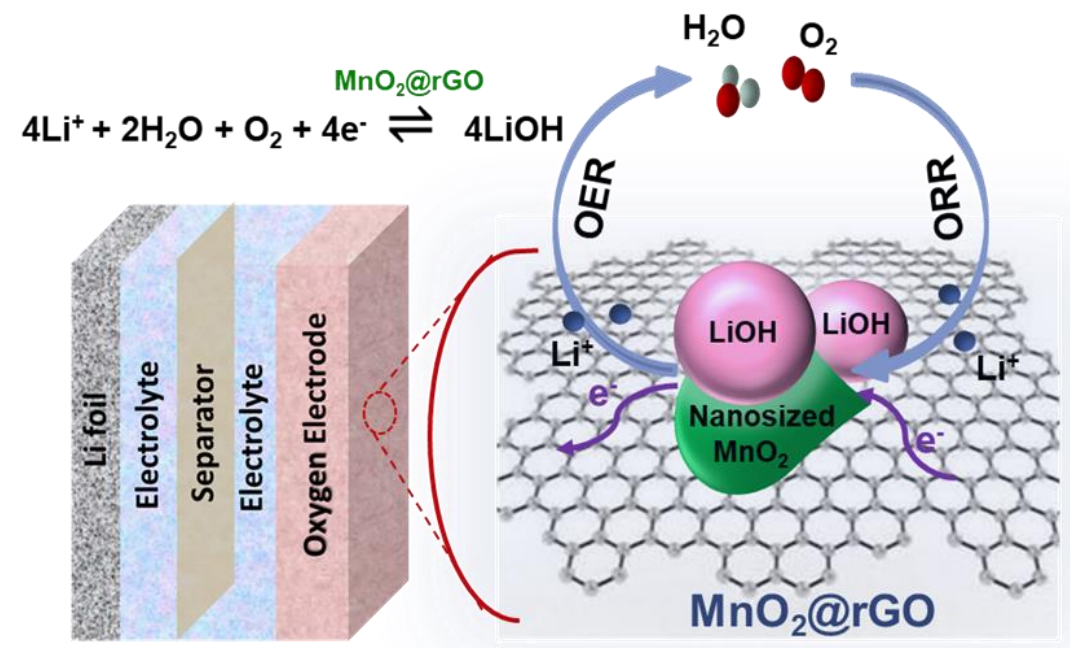

ACS Paragon Plus Environment 